Meddelande från Kulturgeografiska institutionen $\mathrm{Nr} 148$

Geographies of Place Branding

Researching through small and medium-sized cities 



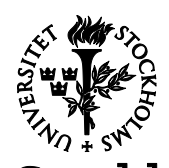

Stockholm

University

\title{
Geographies of Place Branding
}

Researching through small and medium-sized cities

\author{
Ida Andersson
}


(C)Ida Andersson, Stockholm University 2015

Cover illustration: (c)Annika Söderberg

ISSN 0585-3508

ISBN 978-91-7649-144-7

Printed in Sweden by Holmbergs, Malmö 2015

Distributor: Publit 


\section{Abstract}

Place branding is commonly conceptualized with a focus on big cities, such as London, New York and Singapore, building from concepts and models from mainstream branding theory. In contrast to such conceptualizations, this thesis focuses on place branding in small and medium-sized cities.

This thesis aims to study place branding from a geographical perspective. It starts with debates theoretical and empirical understandings of place branding; what it is and how it is affecting the places where it is introduced. The thesis develops and argues for a perspective of territoriality and relationality to place branding discussing concepts, methods and empirical approaches to carry out place branding research using geographical perspectives.

Empirically, this thesis focuses on in-depth case studies of place branding in small and medium-sized cities in Sweden. By analyzing the development of place branding over the course of time, nuances and aspects of both territorial and relational origin emerge, situating place branding practices within a wider spatial contextualization. Four individual papers are presented, which taken together contribute to the aim of the thesis. Paper 1 introduces the place branding research field in geography and how it has developed; Paper 2 investigates the phenomena of flagship buildings located in small cities and towns; Paper 3 discusses the relationship between policy tourism and place branding; and Paper 4 analyzes how local environmental policies are affected by green place branding.

The thesis demonstrates the complex and continuously interchangeable spatial structures and place contexts that create and re-produce the geographies of place branding. Here, research models and methodological examples are presented to illustrate how place branding can be studied from a geographical perspective and thus improve theoretical understandings of place branding. 



\section{Contents}

1. Introduction: The emergence of place branding .................................. 13

What activities does place branding involve? .......................................................... 17

Why is place branding an important subject for research? ........................................ 18

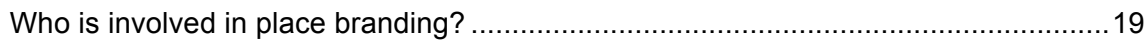

What is the problem with place branding research today? ................................20

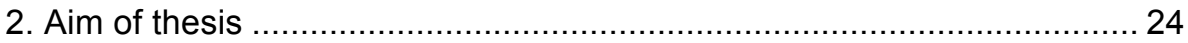

Task 1: Introduce and discuss a conceptualization of place branding from a

geographical perspective................................................................................24

Task 2: Apply and discuss a number of methods on how to research place branding

from a geographical perspective ..................................................................2 24

Task 3: Highlight and address a gap in the research literature, by researching place

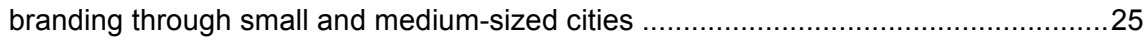

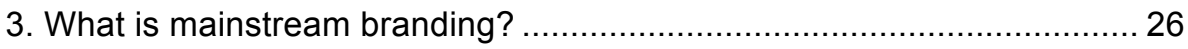

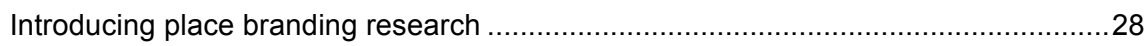

4. Introducing a geographical perspective to place branding...................... 33

5. Conceptual considerations for the geographies of place branding .......... 37

The territoriality and relationality of place branding practices.....................................38

$\ldots$ and their mutational and mobilizing effects on place branding strategies................39

6. Methodological considerations and sources .................................. 42

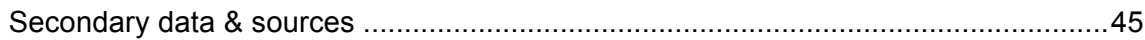

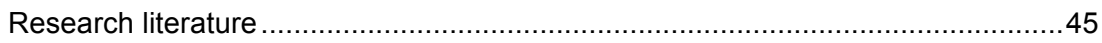

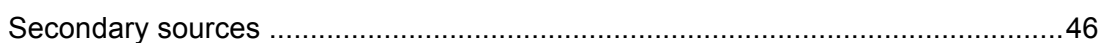

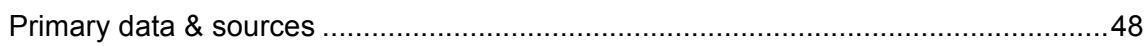

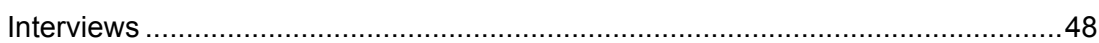

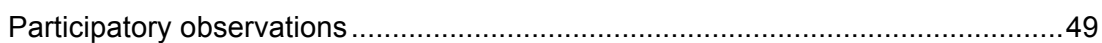

7. Structure of thesis and summary of papers .................................... 52

Paper I: Placing place branding: an analysis of an emerging research field in human

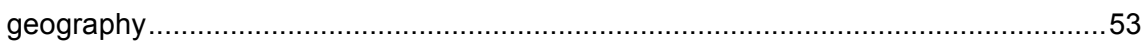

Paper II: Beyond "Guggenheiming": From flagship buildings to flagship space in

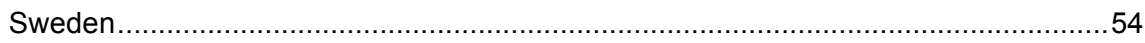

Paper III: From the greenest city in Europe to green heptathlon: place branding and policy tourism in Växjö, Sweden (Co-authored with Laura James). 
Paper IV: "Green cities" going greener? Local environmental policymaking and place

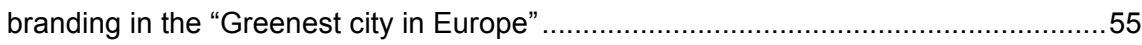

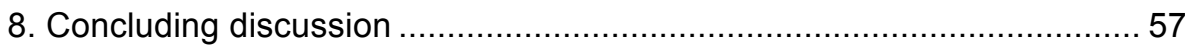
Task 1: Introduce and discuss a conceptualization of place branding from a geographical perspective............................................................................5

Task 2: Apply and discuss a number of methods on how to research place branding from a geographical perspective .........................................................................58

Task 3: Highlight and address a gap in the research literature, by researching place branding through small and medium-sized cities .................................................6 60

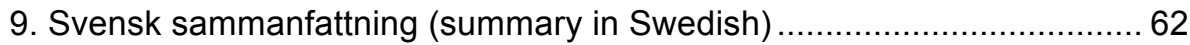

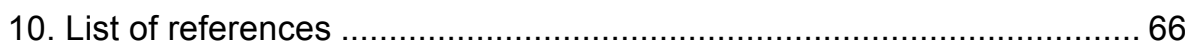

Appendix A. List of interviews and participatory observations ................... 71

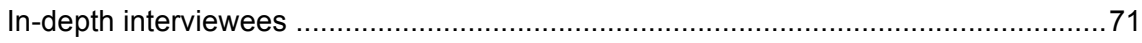

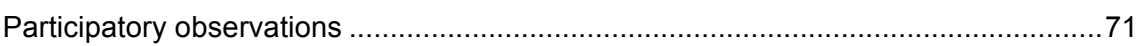




\section{List of Papers}

\section{Paper I}

Andersson, Ida (2014) Placing place branding: an analysis of an emerging research field in human geography. Danish Journal of Geography, 114.2, 143155.

\section{Paper II}

Andersson, Ida (2014) Beyond "Guggenheiming": From flagship buildings to flagship space in Sweden. Norwegian Journal of Geography, 68.4, 228-237.

\section{Paper III}

Andersson, Ida \& James, Laura. From the greenest city in Europe to green heptathlon: place branding and policy tourism in Växjö, Sweden, Manuscript submitted to International Journal of Urban and Regional Research (IJURR).

\section{Paper IV}

Andersson, Ida. "Green cities" going greener? Local environmental policymaking and place branding in the "Greenest city in Europe", Manuscript submitted to European Planning Studies. 


\section{Figures and Tables}

\section{Figures}

Figure 1. The development of place branding - a timeline.....................................28

Figure 2. Case study sites in Sweden ................................................................. 44

Figure 3. Photo showing tourbus during technical visit in Växjö ..............................51

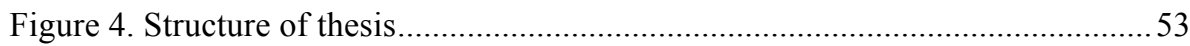

\section{Tables}

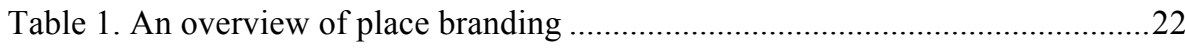

Table 2. Overview of the sources used in separate papers ..................................45 


\section{Acknowledgements}

When thinking about doing a PhD you must come up with a good and interesting project idea that you can imagine yourself working on for at least four years. The idea behind this project is a lot older than four years and was born after a "fika" in Uppsala with Thomas Niedomysl, where we discussed an article about place branding pastry. Thank you Thomas for showing me this article and for all the discussions about place branding we have had over the years. Later, when I was admitted to the PhD program at Stockholm University I was at the time working in the financial sector in Stockholm. I will always be grateful to my former boss Peter Berg who encouraged me to follow my dream of doing research and muster the courage to pursuit this project, even if it meant leaving the team for something completely new.

$\mathrm{A} \mathrm{PhD}$ Candidate is also in need of great support and a stimulating work environment. At the Department of Human Geography at Stockholm University I have had the best support team ever and really nice colleagues. First of all I would like to thank my supervisors Brita Hermelin (nowadays at Linköping University) and Gunnel Forsberg for their constructive and diligent feedback on my research. Without their guidance and support none of this would have been possible. Thanks are also due to Bo Malmberg, Lotta Hedberg and Ulf Jansson for their support and efforts during their respective time as director of the PhD program. From Lotta Wistedt and Iris Claësson I have received administrative support and Stefan Ene have helped me with my maps - thank you all. A special heartfelt thanks to my friends Natasha Webster and Emmeline Laszlo Ambjörnsson, and to all my former roommates - Qian Zhang, Brian Kuns, Estelle Conraux, Tola Gemechu Ango, Alexandre Dubois, Thomas Wimark and Ian R. Cook - who have made every day as a PhD candidate the time of my life. I would also like to thank the Economic Geography Group: Kristina Westermark, Kristina Trygg and Laura James, for excellent collaboration in all sorts of economic geography duties - teaching, research, conferences - and for providing a special sense of belonging at the department. Thanks also to Veronica Hohl and Martina Angela Caretta for fun times and great talks.

At the same time, research can't be carried out without funding, and I am deeply grateful for the generous research funding I have received from Bergströms fund, Lagrelius fund, Mannerfeld fund, Rhodin fund and the Swedish Society for Anthropology and Geography (SSAG). Thanks also to all my in- 
formants who have most generously given me of their time for the purpose of this project.

As a $\mathrm{PhD}$ candidate you are sometimes in need of distractions to take you away from your research and focus on something completely different. I would like to take the opportunity and thank all my friends from the rowing clubs in Uppsala and Hammarby for their excellent provision of much needed distraction. A special big thanks to the ladies of "UARS Tjejsatsning" and to my comrade-in-arms on-and-off the water Malin Bergner, who always have an adventure planned that takes us to new places and racecourses. I would also like to thank the "Friday run club" at the department in whose company I have enjoyed many great outings around SU campus and beyond.

When working on a $\mathrm{PhD}$ project you tend to find yourself in an emotional rollercoaster, and sometimes you doubt yourself, fear that you are in over your head and that you won't make it to the end. Then you are in need of some love, care and encouragement. In this matter I have been blessed. There are many people who have supported me throughout this journey, to whom I am truly grateful. A special big thank you to Annika Söderberg, who is the best friend one could ever have and also the accomplished artist who made the cover of this book; and thank you to my dear friend Anna Olsson for valuable comments and proofreading. Thank you also to my siblings Erika and Emil and their families for all of their support and encouragement. Thanks to my mother and father for their immense support and all kind words, and for always having my back. Finally I would like to say thank you to Fredrik. For everything.

Tullinge, April 14, 2015

Ida Andersson 


\section{Introduction: The emergence of place branding}

"What is place branding? The easy answer to this central question is that place branding is merely the application of product branding to places"

(Kavaratzis \& Ashworth, 2005: 508)

This quote represent in many ways how the practice of marketing and promoting places - often referred to as place branding - is commonly conceptualized. As a practice, some claim that the promotion of places has been on-going for centuries where the Eifel Tower, the Egyptian pyramids and the selling of the American "wild west" have been mentioned as examples of such practices (cf. Ashworth, 2009; Ward, 1998). As a research topic, place branding has been traced to the mid-1950s, and is claimed to connect streams of literature from marketing, tourism and geography (Hankinson, 2015). However, in the contemporary conceptualizations of place branding, the dominant perspectives align place branding practices with business concepts and ideas, and little consideration have been taken to its spatial connotations and associations (McCann, 2009; van Ham, 2008).

Place branding is often described as the ambition of local governments to attract social and financial capital to a certain place. Deriving from a notion of intra-urban competition, place branding has been launched as a global strategy to attract people and money to a city, region or nation (Dinnie, 2011; Paul, 2004). To aid in this endeavor, it has become a common practice among local governments to develop and circulate certain images of the quality of life, location and convenience of the places that they represent through, e.g., slogans, logotypes, urban re-development projects, the hosting of cultural festivals and sport events to build a reputation and establish a relationship - a brand - with different target groups (i.e., inhabitants, visitors, investors, export markets).

In recent years, a number of scholars have called for a re-conceptualization of place branding (cf. Ashworth, Kavaratzis, \& Warnaby, 2015; Lucarelli \& Berg, 2011; McCann, 2009; Niedomysl \& Jonasson, 2012; Pike, 2009; 2011c; 2013). These scholars represent different disciplinary backgrounds in marketing and geography. Since the introduction of place branding as a research topic through seminal publications such as Ashworth and Voogd's (1990) "Selling places" and "Marketing places" - inspired by marketing theories and con- 
cepts by Kotler et al. (1993), place branding as a research topic has generated thousands of publications and a number of thematic journals and conferences (cf. Lucarelli \& Berg, 2011; Pike, 2011c). However, despite more than two decades of diligent research by scholars from a multitude of disciplines, place branding as a research domain faces a major problem, according to Ashworth et al. (2015), specifically, the problem that "place branding still lacks a clear and commonly accepted theoretical framework" (p. 2).

One main reason for the call for conceptual cohesion is based on the apprehension that "almost nobody agrees on what, exactly, place branding means" (Anholt, 2004:4, see also Hankinson, 2001). Being a concept that to a large extent originated in the mainstream branding of products and corporations, the transference of commercial models, theories and management principles to places has been problematic (cf. Hankinson, 2015; McCann, 2009; 2013). One of the most obvious challenges related to this transference is the fact that places, unlike corporations, do not answer to a group of company shareholders but rather to various local stakeholders, such as residents and organizations (profit and non-profit), with different objectives and units of measurements to evaluate the effects of place branding efforts.

In a number of recent publications by Pike (2009; 2011c; 2013), the issue of re-conceptualization of place branding is approached from a different perspective. Instead of delving deeper into "recent developments in broader marketing thought and practice" to assist in the further theoretical development of place branding, as suggested by Ashworth et al. (2015: 2-3), Pike (2011a) argues that "more spatially aware readings of brands and branding offer a means of lifting their mystical veils to illuminate and explain their geographical associations and connotations" (p. 326).

Brands and branding are geographical in essence, Pike (2011c) claims, because they "intersect... economic, social, cultural and political worlds" (p. 4) through their uneven geographical distribution and social-spatial interpretation. Brands and branding can be understood in different ways in different geographical settings, and therefore, a spatial conceptualization is fundamental to understanding branding, according to Pike (2009). Simultaneously, brands and branding are an under-investigated area in geography, creating a gap in the literature between the research conducted and the conceptualizations called for (Pike, 2013). However, how would 'more spatially aware readings' of place branding be introduced, and how can they contribute to the reconceptualization of and research on place branding? These are the main issues that will be addressed in this thesis.

However, before going deeper into this discussion on the reconceptualization of this research field, a few basic questions about place branding must be addressed, such as: What activities does place branding involve? Why is it an important subject for research? Who is involved in place branding? What is the "problem" with place branding today that has generated this debate on its re-conceptualization? These are a few of the issues that will 
be addressed in this introduction and that will set the stage for the continuation of this thesis, which will lead to a more detailed contextualization of the aim and conceptual considerations. In table 1 below an overview of place branding is presented.

\section{What activities does place branding involve?}

Place branding is a concept in policymaking that draws together a number of strategies and practices carried out primarily by local governments. The objective of place branding is to attract mobile resources to a certain place, commonly in the form of social, economic or cultural capital, in response to the apprehension of increasing competition between places (see papers 1 and 4). Place branding is often argued for, by both politicians and place branding consultants, as a necessity for a city to "survive" global competition and not be "wiped off the map" (Hospers, 2006: 1015).

On a general level, place branding is often experienced in everyday life through a city slogan such as "I $\vee$ NY" (McCann, 2009) and "Stockholm - the Capital of Scandinavia" (Stålnacke \& Andersson, 2014), large-scale events such as the Olympics (Waitt, 1999) and the Eurovision Song Contest (Andersson \& Niedomysl, 2010) or commercials for exotic holiday destinations. In addition, various forms of communication on websites and in brochures that present place-based imaginaries are other common expressions of place branding. Together, these are all examples of how local governments increasingly attempt to improve the image of their city, region or nation to enhance its attractiveness as a place to live, work and recreate.

In this thesis, the concept and practices of place branding are analyzed through two empirical examples presented in three different empirical papers. The thesis also contains one paper with a more conceptual analysis to place branding presenting a literature review on the place branding research in the field of human geography (paper 1). In this literature, place branding is analyzed across a broad range of activities, from monuments and mega-projects to sports events, festivals, cultural districts and residential areas. Common for most of this research, however, is that it draws on perspectives and concepts found outside of the traditional mainstream place branding literature.

The first empirical paper (paper 2) studies so-called flagship buildings, which have been one of the most historically frequent ways for a city to promote and attract attention to itself, as exemplified by the Eifel Tower in Paris and the Opera House in Sydney (cf. Smith \& Strand, 2011; Ward, 1998). In this thesis, place branding through flagship buildings is analyzed in relation to the development of spectacular flagship hotels in five small Swedish municipalities.

The second empirical paper (paper 3) studies a less debated technique of place branding. This technique involves the tradition and motives of local 
governments to promote their local policymaking for the purpose of place branding and attracting so-called policy tourists. The frequent trips taken by politicians and policymakers to various destinations in search of 'best' places and 'best practice' policies constitute the foundation for policy tourism. For local governments, receiving such visits presents an opportunity to further enhance their internal image as a 'best practice' while simultaneously branding their city internationally. Commonly contextualized in the research literature by policy experts travelling to learn more about the 'Guggenheiming' of Bilbao (cf. Gonzalez, 2011) and the 'Singapore model' (Pow, 2014), policy tourism is here examined in terms of urban environmental policymaking and international policy tourists' visits to a medium-sized city in Sweden.

The third empirical paper (paper 4) is also concerned with the use of policy for the purpose of place branding. This place branding technique is often deployed in 'green city capitals' such as Vancouver (McCann, 2013) and Copenhagen (Anderberg \& Clark, 2013) that use local environmental policymaking as basis for place branding. Remaining in the same topical context, policybased place branding is here analyzed in relation to Växjö, a medium-sized Swedish city branding itself as "the Greenest city in Europe" and the paper investigates how green place branding impacts local environmental policymaking.

\section{Why is place branding an important subject for research?}

One easy way to answer the question of why place branding is an important topic for research is simply because it is to a large extent financed with public money collected through tax revenues and other public incomes. Public funds are a scarce resource, and in this situation, cities, regions and nations seem to spend increasingly amounts of money on place branding (cf. Andersson \& Niedomysl, 2010; Ashworth et al., 2015; Seisdedos, 2006).

Another motive for this research is that increasingly more places are engaging in place branding. As a reflection of this growing practice, most of the studies conducted in this research field are based on case studies of different places where place branding has been or is currently being implemented (cf. Hankinson, 2015; Lucarelli \& Berg, 2011; Pike, 2011a; see also paper 1). The trend of increasingly more places engaging in place branding has also been observed by Paul (2004), who claims that "attracting global fixed capital investment (corporate headquarters, production facilities, downtown skyscrapers) and circulating capital (transport, tourism, cultural events) through an international identity has become a nearly universal economic strategy" (p. 572). With a rather simple logic that research should be connected to empirical phenomena, this increase in the number of places engaged in place branding calls for studies that focus on who is doing it and with what motives? 
A third incentive for studying place branding relates to how this field has historically developed. Without forgoing a more in-depth analysis of what is problematic with the current conceptualizations of place branding research, studying this topic can simply be motivated by the fact that it has been developed by academics, practitioners and self-proclaimed consultancy experts over the course of the last 20 years, which has given the field a sprawling and eclectic character that lacks cohesiveness (Dinnie, 2004; Niedomysl \& Jonasson, 2012). This in itself "necessitates the re-examination of place branding theory and practice" based on solid academic contributions (Ashworth et al., 2015: 2).

Fourth, place branding has also been connected to larger societal processes and convulsions. One such process is the effect of globalization and the increasing connectivity to the rest of the world, which has made local governments become more uncertain of their economic future. Here, the competition with and co-dependency of other places is suggested to create a need for new types of strategic planning (Malecki, 2004; Paul, 2004), of which place branding is considered to offer guidance and management principles.

In addition, structural changes in the nation state, where a shift in politics during the last two decades from income distribution between regions to policies of regional economic growth has been identified as a factor propelling place branding (Dannestam, 2008; Kotler et al., 1993; van Ham, 2008). Cities and regions are becoming more politically independent, but this development has also led to an increasing burden of responsibility for financial sustainability that cities and regions - often seeking more growth-orientated policies must shoulder (Dannestam, 2008). The earlier welfare policies have been replaced by economic growth policies, and this shift has created a new focus on place-bound economic development for local governments, which thus turn to place branding, as van Ham (2008), among others, has argued.

\section{Who is involved in place branding?}

Place branding activities are commonly initiated by public authorities such as local governments or in public-private partnerships and governance interactions (Kavaratzis \& Ashworth, 2005; van Ham, 2008). In a few rare cases, private interest groups and corporations have initiated place branding strategies typically to build a place identity related to a certain product (cf. Pike, 2011 b; Rusten, Bryson, \& Aarflot, 2007). Simultaneously, it can be noted that the use of famous local products or corporations by local governments for the purpose of place branding is more common (see paper 2).

Place branding practices are also propelled by an influential and growing group of place branding consultants. International consultancy firms offering place branding services that target local governments (e.g., companies such as Brand horizons, Geobrands, Destination Branding, Tendensor) are growing in 
number, as are the number of reports, rankings and evaluations published by consultancy firms that list the "best" places and place brands (e.g., PriceWaterhouseCooper's Cities of Tomorrow, Siemens' Green cities).

However, place branding is concerned with not only an ambition to establish and communicate a certain image of a place but also how its presumed audience perceives this communication. According to Kotler et al. (1993), there are four main target groups - or audiences - for place branding: inward investments (i.e., corporate representatives), inhabitants, visitors and external export markets. It is in this interaction between the initiators of place branding activities and the target groups for them that place brands are created. Place "branding is a mode of communication and communication is always a twoway process" (Kavaratzis \& Ashworth, 2005: 508), which means that actors on both the producing side and consuming side of place brands are involved in the branding process.

Therefore, although local citizens seldom initiate place branding projects or activities themselves, they are considered to play an important role in the place branding process. Place images and place identities are constructed, carried and communicated by individuals, and proud citizens who speak well of their place of residence are considered to be potentially the most powerful ambassadors of positive place images and place brands (cf. Edensor \& Millington, 2008; Zimmerbauer, 2011). Furthermore, a strong local place identity can function as a "means of constructing citizens' sense of themselves and their obligations" (Brand, 2007: 628), which encourages local populations to contribute to enhancing a local place brand through their own conduct (see also McCann, 2013).

A similar role is played by visitors and tourists, who "digest" different places through travelling and are thought to communicate positive (or negative) place experiences from their journeys to their wider circles of peers. In addition, visitors to a certain place also participate in upholding certain place identities by incorporating themselves in local activities, such as riding in gondolas in Venice or bicycling around Amsterdam, and by consuming iconic or ethnic crafts and products when visiting a certain destination (BickfordSmith, 2009; Connell \& Rugendyke, 2010; Johansson \& Cornebise, 2010; Paolo Russo \& Sans, 2009).

\section{What is the problem with place branding research today?}

Place branding research is often greeted with both skepticism and criticism among scholars outside this research domain, according to van Ham (2008). The main reasons for this skepticism can be traced to a number of uncertainties related to the research field:

As noted above, it has been argued that place branding research lacks a cohesive theoretical framework. This lack is suggested to make it difficult for 
researchers to draw any wider theoretical conclusions from the research conducted in the field of place branding. From a broader perspective, it has also been argued to inhibit linking important findings from different case studies together to build conceptual understandings and to advance the theoretical development of the field (cf. Ashworth, et al., 2015; Niedomysl \& Jonasson, 2012).

In addition, the conceptual elements that in fact are used in place branding theory are mainly gathered from mainstream branding. Originally developed in relation to products and corporations, mainstream branding has proven difficult to translate to places (Anholt, 2011; Hankinson, 2015; McCann, 2009). In mainstream branding, "there is no one accepted definition of a brand" (Hankinson, 2001: 128), and instead a brand is described through a number of factors or categories that sometimes, but not always, interrelate, which makes the conceptualization of what constitutes a place brand a difficult task, based on such theories (see also Anholt, 2004; 2010). On a related note, the crossreferencing of place branding research between scholars working in different disciplinary traditions is held to a bare minimum. Although repeatedly described as a cross-disciplinary research field (cf. Dinnie, 2011; Hanna \& Rowley, 2008; Lucarelli \& Berg, 2011), place branding research is commonly conducted in a mono-disciplinary perspective. This reluctance to cite scholars from research traditions other than one's own creates confusion, misunderstanding and skepticism between researchers in different disciplinary topics working on place branding (e.g., Hankinson, 2015; Skinner, 2008).

Furthermore, much of the research published in place branding has a somewhat "descriptive approach" (Berglund \& Olsson, 2010) that promotes certain place branding practices and techniques. The results from descriptive case studies are frequently used by a growing assembly of place branding consultants who present such studies as "evidence" of the effectiveness of said techniques and strategies (cf. Ashworth, et al., 2015; Dinnie, 2004). However, there are scarce empirical findings from actual research work that support these findings on a more general level (cf. Niedomysl \& Jonasson, 2012; Pike, $2011 \mathrm{c}$ ). Thus, there are reasons to question the claimed (generic) effects of place branding. In addition, in this research field, a number of different geographical entities, such as city/destination/region/location/nation, are frequently used together with the term branding to form an object for study. This variety in wording is sometimes described as problematic for the conceptualization of place branding argued to cause further conceptual disparities (cf. Hanna \& Rowley, 2008). However, as Hankinson (2015) notes, instead of regarding these geographical entities as several different concepts, they should be "recognized as alternative manifestations of place" (p.14) and thus together contribute to the conceptualization of place branding (as an umbrella term).

Finally, most of the research on place branding is conducted with an empirical focus on larger cities and capitals (cf. Lucarelli \& Berg, 2011; see also paper 1). Consequently, Syssner (2010) argues that most place branding re- 
search is developed with "a monolithic understanding of space" that disregards any scale-related or territorial variations between urban, rural, global and local spaces (see also Niedomysl \& Jonasson, 2012).

\begin{tabular}{ll}
\hline An overview of place branding & \\
\hline What activities does it involve? & Flagship buildings \\
& Events \\
& Policymaking \\
& Slogans \\
& Commercials, various media coverage \\
\hline Why is it important for research? & Increased public spending \\
& More and more places are doing it \\
& Expected outcomes not accounted for \\
& Connects to economic globalization \& \\
political structural changes \\
\hline Who is involved in its activities? & Local governments \\
& Public-private partnerships \\
& Inhabitants \\
& Investors \\
& Visitors \\
"Consumers" of products and places, \\
export markets \\
\hline Lack of conceptual cohesion \\
Build from mainstream branding with \\
little spatial conceptualization \\
No clear definition of brand \\
Consultants use descriptive research as \\
"evidence" \\
Little exchange between disciplines or \\
conceptual input from others than market- \\
ers, despite being inter-disciplinary re- \\
search field \\
City/region/nation used as different con- \\
cepts, instead as various manifestations of \\
place \\
Mostly researched in big cities and capi- \\
tals \\
\hline
\end{tabular}

Table 1. An overview of place branding (source: own adaptation).

Taken together, between the growing empirical practice of place branding (associated with increased public spending) and the conceptualizations of the phenomena, it is clear that there is a gap in the research field of place branding that fails to fully understand why and with what effects local governments 
engage in place branding and what geographical variations one could expect in these practices. There is a tension between place branding theory and the complex nature of places that must be advanced, highlighting the intersections of politics, economics, society and culture that together form what can be understood as geographies of place branding. 


\section{Aim of thesis}

This thesis aims to contribute to the geographical understanding and research practice of place branding by presenting in-depth empirical studies on place branding situated in small and medium-sized cities in Sweden. On a general level, the thesis draws on Pike's (2009; 2011a; 2011c; 2014) discussion of the geographies of brands and branding, and it seeks to contribute to the debate on the re-conceptualization of place branding (Ashworth et al., 2015; Lucarelli \& Berg, 2011; McCann, 2009; Niedomysl \& Jonasson, 2012; Pike, 2011a; 2013).

The aim is addressed through three different tasks:

\section{Task 1: Introduce and discuss a conceptualization of place branding from a geographical perspective}

Task 1 is addressed in two steps: first, by reviewing and analyzing the spatial conceptualizations of place branding in geographical research and, second, by developing and advocating a perspective of territoriality and relationality towards place branding. This argumentation draws on conclusions in contemporary research in human geography on the potential benefits of joining relational and territorial understandings of place to the advancement of brands and branding geographies (Pike, 2011a). This perspective also implies that place branding in this thesis is understood as something more than product and corporate branding applied to places and that its re-conceptualization lies beyond a framework derived from mainstream branding.

\section{Task 2: Apply and discuss a number of methods on how to research place branding from a geographical perspective}

Task 2 aims at illustrating how spatially informed approaches can prove fruitful for combinations of both empirical research and conceptual development. It promotes the methodological perspective of studying place branding by following different empirical representations of place branding in the form of best practice policies, flagship buildings and place-based competition. The 
ambition is to demonstrate research methods that enable spatial analysis over time and to contribute to the research field by presenting methodological frameworks that do not rely on the imprecise definitions of brands.

\section{Task 3: Highlight and address a gap in the research literature, by researching place branding through small and medium-sized cities}

Task 3 does not only shed light on an under-developed field of study in place branding research but also informs the other two tasks listed above. First, it advances the conceptualization of place branding from a geographical perspective because it scrutinizes existing concepts and theoretical assumptions in an empirical setting beyond large cities and capitals. Second, it aids in the methodological development of place branding research by launching a discussion on geographical size with regards to place branding and providing new suggestions for how place branding can be studied through a range of empirical techniques and perspectives.

Because this thesis is a compilation thesis, the individual papers all have individual aims for more specific and narrow research endeavors. However, through this comprehensive summary, the purpose is to bring the papers together and to highlight the common geographical aspects of place branding advanced in the individual papers.

To help meet the aim and accomplish the tasks of the thesis, two main streams of literature are addressed and unbundled. One stream concerns the transference of mainstream branding theory to place branding, and the other stream concerns the geographical dimensions of place branding. Both streams of literature will be discussed in the next sections. 


\section{What is mainstream branding?}

From the moment you wake to the moment you fall asleep, brands increasingly surround you in your everyday life. They are on the outside of your toothpaste tube, on the box of your breakfast cereal, on the bus that takes you to the office and in the store on the items you put in your basket when you shop for dinner. Brands are often identified as logotypes and symbols, and they are commonly exemplified through well-known global brands such as Coca-Cola and Nike (cf. Klein, 2000). A basic assumption in the conceptualization of brands and branding is that a "brand is more than a name given to a product; it embodies a whole set of physical and socio-physical attributes and beliefs" (Kavaratzis, 2004: 64). Brands are constructed for products, services and corporations in order for branded objects to be perceived as superior in the eyes of consumers. First developed for consumer products in the 1950s, product branding was introduced to increase customer loyalty and to communicate a message of superiority in relation to competitors (Hankinson, 2015).

As noted above, the exact content of the very term "brand" is a contested matter, and different scholars assign different attributes for its definition (Anholt, 2004; Dinnie, 2004; Hankinson, 2001; 2015; Kavaratzis \& Ashworth, 2005). In an attempt to clarify and summarize the different constructs of brand, Hankinson (2001) lists the following attributes:

1. A brand is built up around a number of visual/verbal triggers such as logotypes, names and symbols that are instantly recognizable for the consumer, and that reminds the consumer of the quality of the branded object.

2. A brand also needs positioning, which concerns the placing of the branded object in a distinguished position in the consumer's mind, through product placement and effective communication.

3. Brands are supposed to be perceived as offering unique added values, which most closely represent what the consumer is looking for (e.g., quality, identity, price, flavor). 
4. A brand also needs an image that in turn focuses on the "feelings, ideas and attitudes... and the effort to differentiate the brand psychologically rather than physically" (Hankinson, 2001: 128).

5. Related to brand image, brand personality describes another aspect of this brand attribute. Branded objects can have different personalities that speak to different consumer groups with different lifestyles (e.g., young people, dog lovers, football fans).

6. Brand perceptions are based on the idea that people are attracted to certain objects based on senses, reason and emotions, and brands should aim to target all three types of appeal.

In summary, it could be said that a brand is built through combining these different attributes. Simultaneously, however, it should be noted that the attributes listed above are only a few of the brand components that have been identified as building blocks for brands in the research on branding (cf. Hankinson, 2015; Kavaratzis 2004; 2005; van Ham, 2008). However, because it is neither the aim nor the scope of this thesis to give an account of all the different variations and combinations of the definitions of brand, this list can be considered to represent a general line of reasoning on how a brand is constructed, particularly in relation to how this concept has moved into the idea of place branding.

Corporate brands in turn are a special approach to the wider concept of brand as summarized above. These were forged from mainstream branding theory in the 1990s, and a corporate brand can be described as an "umbrella brand" for a wider set of products and services, often with different target audiences. Here, a whole organization is branded and given an image, an identity and mode of communication. However, it is not only in the external dialogue but also in the internal dialogue that a corporate brand can add value to a company by providing strong, positive messages about the organizational attributes and core values of the corporation to employees and other stakeholders. As with products, the objective of a corporate brand is to create differentiation and preference for the corporation as such over its competitors, and a strong corporate brand, according to Kavaratzis (2004), is formed through the alignment of corporate visions, cultures and images.

Branding is the set of activities commonly described in terms of the deliberate communication of brands to different target groups; these activities are applied in the branding of consumer products, services and corporations. Branding is an interaction and communication between three different agents: the producer, the retailer and the consumer. Branding is used not only to differentiate the product but also to aid in differentiating the consumer. This capacity has made branding especially important for contemporary consumption 
patterns, where so-called life-style consumption is a growing trend (Kavaratzis $\&$ Ashworth, 2005). Branding can also be understood as a form of soft power that influences people's actions not by the threat of violence or through power "but by 'the ability to attract', which goes beyond influence or persuasion" (van Ham, 2008: 126).

\section{Introducing place branding research}

Although presented as a research field that developed in the 1990s, place branding research traces further back in history. As a practice, place branding, for instance, can be linked to the selling of the American "wild west" in the mid-1800s (Ward, 1998). The use of flagship buildings to demonstrate wealth and power can be traced back as far as the Coliseum and the Parthenon in antiquity (Ashworth, 2009). However, in academia, the article "Image as a factor in tourism development" by John D. Hunt (1975) has been identified as marking the beginning of research on place branding, according to Sonya Hanna and Jennifer Rowley (2008). Initially studied in the tourism discipline under the name "destination branding", place branding was further developed in the article "Selling Places" by geographer Jacquelin A. Burgess (1982), as claimed by Hanna and Rowley.

To contrast and complement this historical review of the research field, Graham Hankinson (2015) has investigated the conceptual origins of place branding research even further, incorporating the findings of Hanna and Rowley (2008), and placed them in a broader theoretical linage and perspective. In figure 1 below, a timeline of the development of place branding theory, according to Hankinson, is presented.

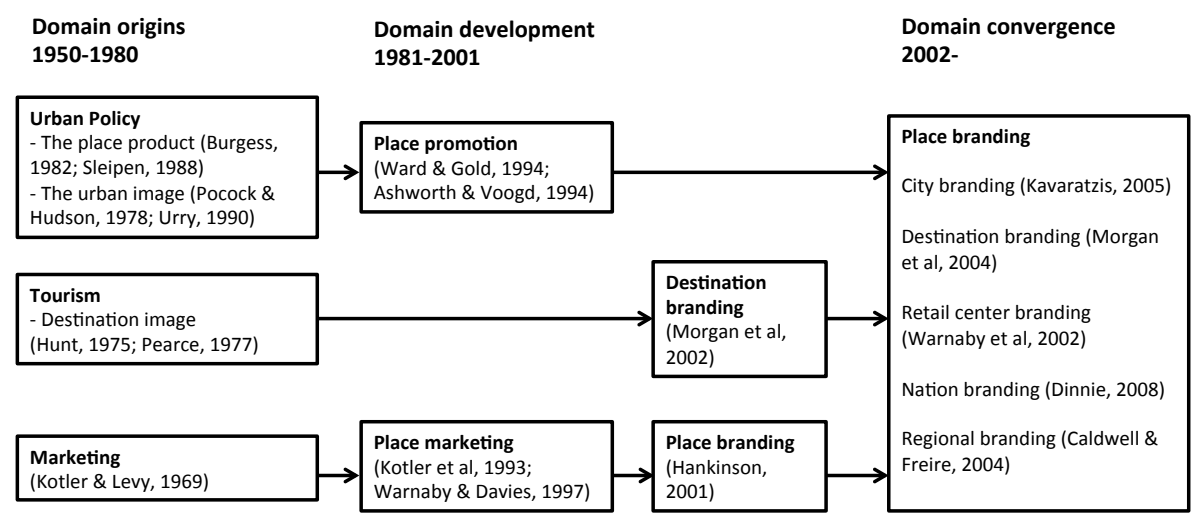

Figure 1. The development of place branding - a timeline (source: Hankinson, 2015).

As figure 1 illustrates, Hankinson (2015) traces place branding back to three main research themes: urban policy, tourism and marketing. To me, this array 
of the development of place branding adds interesting and fresh perspectives to the conceptualization of this research field. With this line-up, Hankinson demonstrates that place branding has a broader conceptual background than previous studies, which have primarily connected place branding to the academic tradition of marketing research, with some early connections to tourism, have suggested (cf. Hanna \& Rowley, 2008; Kavaratzis, 2004; 2005).

Another novelty that follows from Hankinson's line of reasoning is that place branding here can be understood as an umbrella concept that encapsulates a number of different geographical and conceptual sub-sets, each focusing on different types and scales of place branding. With this perspective, the use of different terminologies, such as city branding, destination branding, and nation branding, should not be regarded as conflicting - and barely compatible - perspectives (cf. Hanna \& Rowley, 2008) but rather as different geographical connotations of place branding. By adopting this approach, place branding studies on various geographical levels and scales have the potential to complement and support each other and not, as previously suggested, to contribute to an increased fragmentation of the research field (Berglund \& Olsson, 2010; Hankinson, 2015; Warnaby et al., 2015).

Despite the somewhat scattered theoretical origins illustrated in figure 1, place branding is commonly initially described as "the application of product branding to places" (Kavaratzis \& Ashworth, 2005: 508; see also Anholt, 2015; Kavaratzis, 2004; Lucarelli \& Berg, 2011). Branding is perceived to present a more distinct and particular identity for products, which is also what place branding aims to do for places (Kavaratzis, 2004; Kotler et al., 1993). A place brand is created through communication between the "seller" of a place, i.e., the "institutions that undertake place branding projects", and potential "buyers" of that place, i.e., "place consumers who make place-related decisions" (Ashworth et al., 2015: 5).

Simultaneously, place branding also presents a somewhat holistic view of the management of places because it is suggested to be "the conscious application of marketing approaches by public planning agencies not just as an additional instrument for the solution of intractable planning problems but [...] as a philosophy of place management" (Kavaratzis, 2004: 29, my emphasis). Place branding also adds an element of time to these activities because "[t]he production of an urban brand is [...] an ongoing process, [and] not a one-off event" (McCann, 2009: 121), which thus links a local government's promotional and marketing activities together into a long-term strategy to create a place brand.

However, because places are often more diverse and multi-facetted than products, place branding is often given a more voluminous definition that draws on the conceptualization of corporate branding. "Place brands resemble corporate umbrella brands to some extent", Kavaratzis and Ashworth (2005:511) explain. Place branding is suggested to present tools for political organizations and local governments to plan, manage and market their city, 
region or nation in a manner similar to how corporate branding provides opportunities for companies to express their core values, beliefs and organizational cultures (cf. Dinnie, 2011; van Ham, 2008; Hankinson, 2001; Kavaratzis, 2005).

This linking of corporate and product branding to place branding has generated critique. In addition to a general critique of place branding as representing a commodification of places and marketization of governmental assignments and practices (cf. McCann, 2009; van Ham, 2008), several critiques of place branding have been introduced. For instance, unlike corporations with a clear management and ownership structure, places are "owned" by a multitude of stakeholders, and this is argued to create democratic issues for place branding. After all, whose brand is it anyway, and who has the right to define what should be included in a place brand? Who decides what is cohesive in a place branding message, and on what grounds are such decisions based? These are some of the democratic issues that have been raised as response to the argument that corporate branding provides a suitable framework for places (cf. Franzén, 2010; Gotham, 2007).

To address this critique, it has been suggested that a network and collaborative approach to place branding can provide a means for decision making beyond a small group of urban/regional elites (cf. Dinnie, 2011). Similar to this line of reasoning, suggestions have been made to increase the involvement of residents (Zenker, 2010) in the development of place brands and to adopt an "integrated approach" (Braun \& Zenker, 2010; Therkelsen \& Halkier, 2011) where place branding is shaped in a collaborative fashion with the involvement of various brand stakeholders. However, despite such insertions in the academic debate on the transference of mainstream branding to places, scarce theoretical refinement has taken root in the place branding literature (Ashworth et al., 2015).

The theoretical underpinnings of corporate branding is claimed to create another problem for transferring such ides to places. Here, it is argued that mainstream branding provides a simplified view of the management and organization of places, which makes it difficult to translate management principles from companies to places (Andersen \& Wichmann-Matthiessen, 1995). In short, this line of argument is based on the assumption that the responsibilities, flexibility, competences and jurisdictions of a corporation significantly differ from those of a region or a city. A similar critique is directed towards the view that place-based competition is the key process for place branding. Here, it is argued that such a conceptualization does not match the empirical reality of place branding practices because the differentiation of places is not a zero-sum game (Doel \& Hubbard, 2002). No city or region can thrive economically, socially and culturally without the active interaction and collaboration with other cities and regions to translate and mediate global flows of people, capital and ideas. Thus, it is argued that the corporate narrative of competition should 
be replaced by a "politics of flow" in the understanding of place branding (Doel \& Hubbard, 2002).

As noted above, a suggested solution to this problematic conceptualization of place branding has been to further explore mainstream branding theory and practice (cf. Ashworth, 2015; Berglund, 2013). As Hankinson (2015) argues, "place branding research has only just begun to take account of the significant deepening and broadening of the mainstream branding domain" (p. 13). Although this endeavor might prove fruitful in future research, simultaneously, as a geographer, it is difficult not to point to the fact that the concept of place, in the current conceptualization of place branding, is somewhat under-theorized. To date, place is presented at best as something "more" than just a commercialized and temporally fixed object; most of the time place is more or less understood as a container for the different actors involved in the communicative process of branding.

Although many writers have highlighted the fact that places are not "just spatially extended products that require little special attention as a consequence of their spatiality" (Kavaratzis \& Ashworth, 2005: 507), local elites engaged in place branding are still eager to cherry-pick the elements of their place's most attractive traits (i.e., its landscape, economy, society and culture) for the purpose of branding (McCann, 2009). This assemblage of selected spatial attributes affects how places are perceived and conceptualized by framing them in a context of commercial relations and transactions (Ek \& Hultman, 2007). That this conceptualization has translated to place branding research can be illustrated in the designation of inhabitants and visitors of places as "end users", "place consumers" and "target audiences", to name only a few examples (Dinnie, 2011; Kavaratzis \& Ashworth, 2005).

In addition, the variation and uniqueness of different places are rarely acknowledged in the research field; instead, places are more or less conceptualized as a flat, unspecific terrain because "many places offer the same "product' - territory, infrastructure, educated people, and an almost identical system of governance" (van Ham, 2008: 129). Additionally, as Niedomysl and Jonasson (2012) note, the scale of different places and the geographical distances between them are scarcely addressed in place branding research; instead, all places are assumed to compete equally with every other place in the global competition over social and financial resources (see also Syssner, 2010). Through place branding, many local authorities and researchers have suggested that the structures of economic development can be altered by strategically addressing the desire to become "a place on the map" (Andersson \& Niedomysl, 2010; paper 3), facing the fear of being "wiped off the map" (Hospers, 2006) or having the capacity "to position themselves as centers of creativity" (Rantisi \& Leslie, 2006), which all communicate a somewhat flat and fixed view of the geographic dimensions involved in place branding.

Thus, in a situation in which mainstream branding theory has so far failed to successfully conceptualize place branding, I argue that perhaps a solution to 
this problem is not to dig deeper into branding theory but rather to take a wider conceptual approach. If place branding can be understood as the application of branding in places, rather than to them, then an approach grounded in a space-sensitive understanding of place is a fruitful point of departure for this re-conceptualizing of place branding theory. 


\section{Introducing a geographical perspective to place branding}

Even before Tuan's (1974) seminal characterization of place as bearing meaning and space as its binary representing the general and unspecific, geographers have been engaged in the study of space and place, emphasizing that the one cannot be understood without the other. Place is commonly described as the lived or the experienced, with practices and encounters, while space is presented as the controlled or commanded, with locations and flows (Agnew, 2005). Place can also be perceived as created bottom-up through localized processes, while space is more top-down and influenced by global power hierarchies and relations. Space, however, is understood as something embodied and consistent, while place is constrained to certain time-space terrains.

The intellectual work on place and space and the relationship between them has generated a number of prominent publications in geography, perhaps most notably those by Lefebvre (1991) and Massey (1994; 2005), which theorize the production of space and place. In the widely cited work "For Space", Massey (2005) presents space as a relational product "always under construction" (p. 9), shaped through interactions and interrelations and therefore never capable of being finished or done. From this perspective, Massey argues, space is always something continuous and heterogeneous, something that could never be reduced solely to a terrain or surface. Examples of how these elementary geographical concepts have inspired place branding research include Torkington's (2012) study of lifestyle migration from northern Europe to Portugal, Kim's (2010) review of the branding practices connected to the newly developed Songdo City in South Korea, and Chang's (2008) analysis of the use of public art as a means for the "soft" branding of Singapore.

Branding is inescapably a geographical matter, Pike (2009) argues, because brands and branding are recognized and interpreted based on people's sociospatial position. Brands and branding are also geographically distributed unevenly and are used to articulate and further enhance socio-spatial differences between different groups and individuals. This line of argument has been further developed by Pike (2011a; 2011c; 2013) and can be claimed to represent a new view on the relationship between place and branding, potentially providing new possibilities for the geographical theorization of both branding and place branding, including the development of new research methodologies. 
As a research field, place branding is expanding in geography (see paper 1), and the traditional connections between geography and place branding have been emphasized by a number of scholars, as noted above (i.e., Hankinson, 2015; Hanna \& Rowley, 2008; see also Hallin, 1991). However, this academic endeavor by geographers has been identified by several marketing researchers as mainly an exercise in criticizing place branding practices while simultaneously ignoring much of mainstream branding theory (Hankinson, 2015; Olsson \& Berglund, 2010). In line with this reasoning but approaching from a different perspective, Pike (2011c; 2013) argues that the connection between brands and branding and their spatial and geographical connotations and entanglements has not been adequately highlighted in geography. The conceptualization of brands and branding is therefore claimed to have been disregarded among scholars in the geographic disciplines.

Simultaneously, over time there have been two main approaches by which geographers have entered into the place branding research field, according to McCann (2009). One approach is derived from a political approach that focuses on place branding as an effect of urban entrepreneurialism (following Harvey, 1989). The other approach derives from a planning perspective that examines the relationship between place branding and the built environment. Both approaches have been closely connected through their examination of various place branding practices. As an example of combining these two traditions, Hall and Hubbard (1998) can be noted. In their study of entrepreneurial cities, they identify place branding as a set of specific policies and strategies deployed in policymaking by local governments and through which promotional activities are incorporated alongside planning and physical developments. Such conceptualizations have not explicitly aimed at refining mainstream place branding theory; instead, they have been framed as conceptual understandings of contemporary policymaking and governance.

In an attempt to bridge this gap between the spatial conceptualizations of place and mainstream branding theories, Pike (2009; 2011a; 2013) points to the explicit spatial entanglements of brands and branding and how they intersect political, economic, social and cultural geographies in various locations. However, when translated to places, the language and discourse of mainstream branding theory indicate that the practices and strategies in the branding of places are universal and easily transferrable (cf. Ashworth's (2009) discussion on the 'instruments of place branding' being 1) personality association, 2) flagship buildings and districts, and 3) event hallmarking), when in fact each implemented place branding strategy is an adaption to local sets of territorial and relational resources (McCann, 2004; 2011; see also paper 2), which calls for a more thorough terminology of place branding. Additionally, as Pike (2011a) notes, a divide has developed between the intentions of place branding - i.e., to differentiate places from each other - and the practice of place branding - i.e., the routine-based copying and borrowing of successful strate- 
gies from one place to another, creating a "serial reproduction" of similar places (Harvey, 1989:10; see also Ooi, 2011).

Anholt (2011) pushes the discussion of transferring models and principles from the corporate sphere to places even further, arguing that the principles for corporate or product branding can never be transferred to places. He uses the case of nation branding as an example and states that "countries aren't for sale, aren't easily mistaken one for another, aren't fast moving consumer goods, and certainly don't come in wrappers, so the principles simply don't transfer" (p. 290). Making a comparison to successful product and corporate brands, Anholt extends his argument, asserting that it is not the branding of these products and corporations that has created broad recognition for these brands. Instead, their status as superior has been achieved through strategic and diligent 'product development', which for local governments translates to good and successful policymaking. In short, Anholt (2011) argues that what makes a brand strong and prosperous is not the outcome of a perfectly orchestrated branding campaign but rather "the result of fantastic products sold in fantastically large numbers" (p. 291). Translated to the context of governmental ambitions to improve their place image, this means that, when a local government wants to improve its city's, region's or nation's reputation and appearance, the content and qualities of what is offered by that government are what matter in the long run, not how well the place brand is communicated. At best, place branding provides a way for local governments to organize their work and guide how they present themselves to the rest of the world, Anholt (2011) concludes.

Without going so far as to dismiss mainstream branding theory altogether in the understanding of place branding, it can be argued that the transference of concepts and ideas from products and corporations to places has generated a number of conceptual mutations. For example, the adoption of place branding practices by local governments has created new relational geographies, Lewis (2011) argues. These geographies have in turn provided new hierarchies and institutions that affect territories, governance and place identities. As an example of what branding has become, with the publication of rankings by various institutions - presenting cities, regions and nations in different categories and through a multitude of lenses (e.g., greenest, most creative, safest, most connected) - the objective of political managers is to be able to advance, or at least maintain the same level, in such rankings from year to year.

In addition, although currently booming in an era of emerging postindustrial economies and closely linked to the practice of urban entrepreneurialism (Harvey, 1989), place branding practices and motives in recent years have transformed, according to Arvidsson (2011). Although earlier place branding activities perhaps could be seen as representing adaptions to structural changes in a "new" economy, place branding has now moved beyond the discourse of place attractiveness and the traditional framework of place-based competition. Through place branding, local governments have developed tools 
for fostering citizens and exercising governance by applying "green", "creative" or "friendly" epithets to their place of living, thus integrating governance into the everyday lives and practices of citizens and promoting certain lifestyles (see also Brand, 2007). Therefore, the understanding of place branding can be argued to expand from a mainstream financial and economic perspective to a wider social and political approach.

Another example of conceptual mutations of place branding theory can be illustrated by McCann's (2013) study on 'policy boosterism', where local governments use locally developed policies, programs, or practices for the purpose of place branding (see also papers 3 and 4). In these policy-based place branding situations, the rationales for establishing place brands and engaging in place branding activities expand beyond the traditional rationale of place-based competition over financial and social capital and are instead redirected towards cooperation between different local governments through policy networks and the use of place branding for the purpose of local governance and planning. This line of argument can be related back to Anholt's (2011) claims that "good" policymaking is essential to the development of a successful and strong place brand.

It is appropriate here to recapitulate the initial questions posed at the beginning of this thesis: "how would 'more spatially aware readings' of place branding be introduced, and how can they contribute to the reconceptualization of and research on place branding?" Now that a firmer literature background and conceptual consideration of place branding and its geographical dimensions have been established, it is appropriate to re-formulate 'more spatially aware readings' into something more precise. This issue will be addressed in the section below. 


\section{Conceptual considerations for the geographies of place branding}

The re-conceptualization of place branding through "more spatially aware readings" was outlined in the section above, and a recently published literature review also shows that this process is currently underway in the field of human geography (see paper 1). According to this review, the research on place branding published in geography feeds into well-established research approaches outside mainstream branding. These results resonate well with earlier findings (cf. Lucarelli \& Berg, 2011) on how geographers have approached place branding research.

To further aid in the endeavor of re-conceptualizing place branding and to further narrow the definition of 'more spatially aware readings' of the geographies of place branding, the concepts of territoriality and relationality are useful. These concepts have engaged scholars working in geography for decades (cf. Brenner, 1998; Harvey, 1982; Massey, 1991); and although different theoretical conclusions have been presented through these studies, it is fairly safe to argue that both territoriality and relationality have provided valuable insights into how cities and places are developed and re-constructed. As Amin (2007: 103) has argued, "it is a subtle folding together of the distant and the proximate, the virtual and the material, presence and absence, flow and stasis, into a single ontological plane upon which location - a place on the map - has come to be relationally and topologically defined". Recently, the tension between relationality and territoriality has inspired a series of publications that discuss processes of urban policy making and the assemblage of cities (cf. Cochrane \& Ward, 2012; McCann, \& Ward, 2010) in regards to place branding practices (cf. Koch, 2014; McCann, 2013; Pow, 2014). Here, territoriality and relationality are crucial to understanding how places and place branding policies are produced.

Through this combined view of the relational and territorial working together and creating tensions that produce and re-produce places, Pike (2011a) has presented arguments with regards to the difficulties of translating mainstream branding theory into places, claiming that "a geographically nuanced approach to territorial and relational notions of space and place... are fruitful in explaining [the] diverse, varied and often contingent development" of brands and branding (p. 325, my emphasis). Following these arguments, the 
concepts of territoriality and relationality in relation to place branding are discussed below.

\section{The territoriality and relationality of place branding practices...}

Starting with the concept of territoriality, which in Harvey's (1982) terms may be understood as the 'spatial fix' of place on policy, in place branding research, territoriality has come to be understood as the materialization of place branding ideas (cf. McNiell \& Tewdwr-Jones, 2003). On a general level, territoriality marks the re-installation of place and territories in the academic debate on spatiality (meeting claims of the 'death of geography') by emphasizing the territorial processes connected to policymaking. Each place presents a certain set of time-space-constrained resources and (infra)structures available in policymaking processes, which can be highlighted and articulated through the territoriality concept. Territoriality also sheds light on policy formation on various geographical scales, Brenner (1999), among others, argues. This perspective has inspired research on place branding from many different perspectives: as re-territorialization of political and economic power through architectural 'mega-projects' (McNeill \& Tewdwr-Jones, 2003), in developing placeand territoriality-specific branding strategies, as opposed to generic and universal strategies (Lorentzen, 2009) and as a crucial component in learning from elsewhere in the study of best practice place branding policies (Klauser, 2011). In a recent publication by Koch (2014) the materialization of branding ideals and policies through events, urban re-development and green city strategizing illustrates how more universal branding ideas are inevitably territorialized when being implemented.

In contrast to the theoretical development inspired by territoriality, its conceptual counterpart relationality can also be said to carry spatial meaning for place branding. Drawing on the widely cited work by Castells (1996), which argues for a 'space of flows', and Massey (1991), which conceptualizes places as nodes within networks of relations, relationality encapsulates the spatially dynamic dimensions of place branding represented in networks, power relations and agency. Relationality stimulates the dissemination of images both externally and internally, which makes it very fitting for the study of place branding, given that success in place branding is evaluated in relation to what other places have accomplished (Lewis, 2011; McCann, 2013). This perspective has inspired research on place branding, perhaps most notably the work interlinking it with the rise of the so-called "creative class" and its assumed effects on the local economy. In Currid's (2009) discussion on art and culture as factors for economic development, the assumed consumption and lifestyle patterns of the creative class become a tool for urban redevelopment and for 
place branding. In Martínez's (2007) study on the development of Antwerp as a fashion capital, place branding is analyzed in relation to the social imaginaries of the creative industries. Additionally, with regards to the diffusion and mobility of so-called 'best practice' policies, the intertwining of relationality and branding perspectives are particularly fruitful because comparisons and rankings of policies are essential to the development, movement and adaption of policy models, which are dependent on the reputation and image of the place promoting them (McCann, 2013; Pow, 2014).

There is a tension between territoriality and relationality that produces policies and places, McCann and Ward (2010) argue. For place branding, this tension implies that the agents engaged in place branding can draw benefits, when implementing their strategies, from the availability of both territorial and relational resources. Simultaneously, territorial and relational resources may also create barriers for implementation because a lack or a presence of the "wrong" resources can potentially inhibit the implementation of certain place branding strategies in particular places (cf. paper 2). For place branding practices, this is often expressed in the manner in which policymakers use the local place-bound qualities (e.g., location, culture, quality of life) and combines them with more generic branding strategies (logotypes, flagship developments, events) to present a unique identity for that place (Ashworth, 2009; Dinnie, 2011). However, with place branding as with policymaking in general, the relationality and interconnectedness of a certain place affect what territorial aspects are selected as tools in local activities and endeavors to develop places. Through networks, nodes and interactions, 'good' branding ideas are shared and diffused, and through territorial interpretation and implementation, place branding ideas and strategies become materialized and spatially fixed.

\section{$\ldots$ and their mutational and mobilizing effects on place branding strategies}

However, territoriality not only induces materialization and fixity of place branding but also causes a conversion from abstract and general place branding ideas to something very place-specific (McCann, 2004; 2010). In the policy mobilities literature, the concept of mutation has come to represent this territorial effect of place on policies, which renders it a term that may also be used for place branding. In the case of policies, Cochrane and Ward (2012) argue that policies do not simply exist in a networked 'space of flows'; at some point or other policies "emerged from and are responses to particular 'local' sets of social and political conditions" (Cochrane \& Ward, 2012:5). This line of reasoning could easily translate into the context of place branding, given that the "uniqueness" of a place very distinctly affects how a generic place branding strategy is rolled out locally. This phenomenon is discussed in 
numerous publications, especially in the "best practice" (Bader \& Scharenberg, 2010; Dixon, Otsuka, \& Abe, 2011) and "bad practice" streams (Stern \& Hall, 2010) in the place branding literature.

By adopting a relationality perspective to place branding, the mobility and diffusion of various place branding ideas and practices can be presented in a new light. Previous research has significantly focused on the copying and borrowing of successful place branding regimes (Ashworth, 2009; Dinnie, 2011), based on the assumption of "what works". Through the lens of relationality, the diffusion and mobility of place branding practices and theories can be related to "who is working", shifting the focus from generic ideas to relational agents and networks (cf. Pike, 2011c; Pow; 2014; Warnaby et al., 2015). In the previous research, so-called place branding consultants have endured heavy criticism from a multitude of scholars for their alleged "pushing" of certain place branding regimes, with little evidence of the success rate of such models (Ashworth, et al., 2015; Dinnie, 2004; Niedomysl \& Jonasson, 2012). However, from a relationality perspective, branding consultants are not the only agents involved in the mobilization and diffusion of place branding ideas and strategies because policymakers, ranking institutions, academics and bureaucrats can also be considered agents involved in the "pushing" of certain place branding models. Drawing on the logic introduced by Prince (2012), it can be argued that no place branding practice or strategy can be mobilized in a social vacuum, and the recognition and value of a certain place branding policy is commonly made with reference to the identity and status of its advocate.

Mutation and mobility are recurring themes in place branding because the copying and borrowing of successful branding ideas and the adaption of them to local conditions are current practices among policymakers engaged in place branding. Commonly expressed as 'benchmarking', the diffusion of "good" place branding policies is guided by social dimensions in networks that function as infrastructure for such mobilization. However, regardless of whether policymakers engage in benchmarking through study tours, conferences or reading books and articles, the success and quality of place branding strategies and practices are evaluated in relation to the social position and brand reputation of their consigner (e.g., being a famous researcher or a leading politician). After all, it is quite possible that a highly mobile and popular place branding strategy simply is not the best one available, but its popularity derives from the fact that the right people in the right social settings have promoted it.

To sum up this discussion on the geographical perspectives on place branding, it is here argued that place branding is affected by the spatial processes of the place where it is implemented and that both territorial and relational aspects of these processes must be taken into consideration to conceptually understand place branding. This means that place branding mutates when it is converted from general ideas to place-specific practices, and vice versa, when place branding is transformed from a place-specific strategy into a generic policy model (i.e., 'best practice'). This variability can be understood as the 
territorial effects of place on place branding theories. Simultaneously, exactly which place branding models and theories that are pushed and acknowledged as 'best practice' are to a great extent dependent on which relational networks and connections the agents involved in place branding possess.

Such are the conceptual considerations that frame this thesis and influence the discussions going forward. 


\section{Methodological considerations and sources}

Traditionally, studies on place branding are conducted with a strong empirical focus. According to Lucarelli and Berg (2011), approximately 65 percent of all research publications in the field are case studies that examine from one to three cases. In geography, these numbers are even higher, with more than 80 percent of the published articles on place branding being based on case studies (see paper 1). The act of branding itself represents a challenge for all researchers empirically studying place branding. Branding is all about the communication of a certain image or story of a branded object, and when a representative of a brand is faced with the exercise of a research interview, the narratives and official storytelling of that brand might come easily for the interviewee (Jackson, Russel, \& Ward, 2011). This risks turning an interview into a branding exercise in itself. The task for the researcher, then, is to attempt to follow the "brand" beyond this type of storytelling and apply a wider empirical frame to prevent the mere collection of the official messaging.

Pike (2011a) suggests the use of a mixed-methods approach to collect both primary and secondary data to provide more plural accounts of branding. However, official branding narratives can be found in all types of communication, not only in an interview situation with a branding agent. Webpages, pamphlets, and TV commercials are all designed to communicate a certain message that is aligned with the official brand. Simultaneously, messages and rhetoric tend to change over time, and therefore, such written communications can be of great value in attempting to "map" the structures and underlying factors behind a brand. By accessing previous official communications (e.g., old pamphlets, brochures, newspaper clips), different temporal dimensions in the branding process can be highlighted (cf. Pow, 2014).

To expand the conceptualization of place branding, Warnaby et al. (2015) suggest that a greater research interest should fall on the agents who are involved in place branding. Methodologically, this can be done from two perspectives: either by focusing on the organizations that undertake place branding projects, i.e., the "producer side", or by a more socially oriented user/citizen perspective that analyzes the groups and individuals who experience place branding, i.e., the "consumer side" (cf. McCann, 2013).

For this thesis, the studied place brands and branding are empirically situated in small and medium-sized cities located in Sweden. This research focus facilitates and provides access to details and layers of the place-specific and more mainstream branding aspects of place branding. In a small geographical 
setting, the number of actors involved is few, the networks are somewhat small and achieving an overview of the place branding processes is comparably easy. Compared to studies on large city regions, this approach offers the possibility of deeper and more thorough work.

In this thesis, I present an organization-centric perspective. This perspective orients interest towards organizational settings and forms for place branding activities. I have also focused on the actors and structures involved in place branding from the production of place branding. To limit the scope of the research and facilitate a greater focus in the analysis, the consumption perspective of place branding is not been included.

A potential risk with relying primarily on accounts and records from the supply side is that the conceptualization of place branding that derives from such a study lacks the capacity to appreciate the interactive dialogue between the producers and consumers of brands that branding is supposed to be. Simultaneously, however, focusing primarily on the "supply side" allows a deeper investigation into the motives and power structures that underpin the development of place branding, which has been noted by several scholars as an important topic for future studies in this field (cf. Arvidsson, 2011; McCann, 2013; Warnaby et al., 2015). Therefore, to countervail any lopsidedness towards only relying on accounts provided by public officials working in local government to grasp the local perspective, articles and other published materials from local newspapers have been collected throughout this research to provide a "second voice" to understand local development and complement the official narratives on how place branding projects have emerged and

progressed. The locations of the case Figure 2. Case study sites in Sweden. study sites are displayed in figure 2.

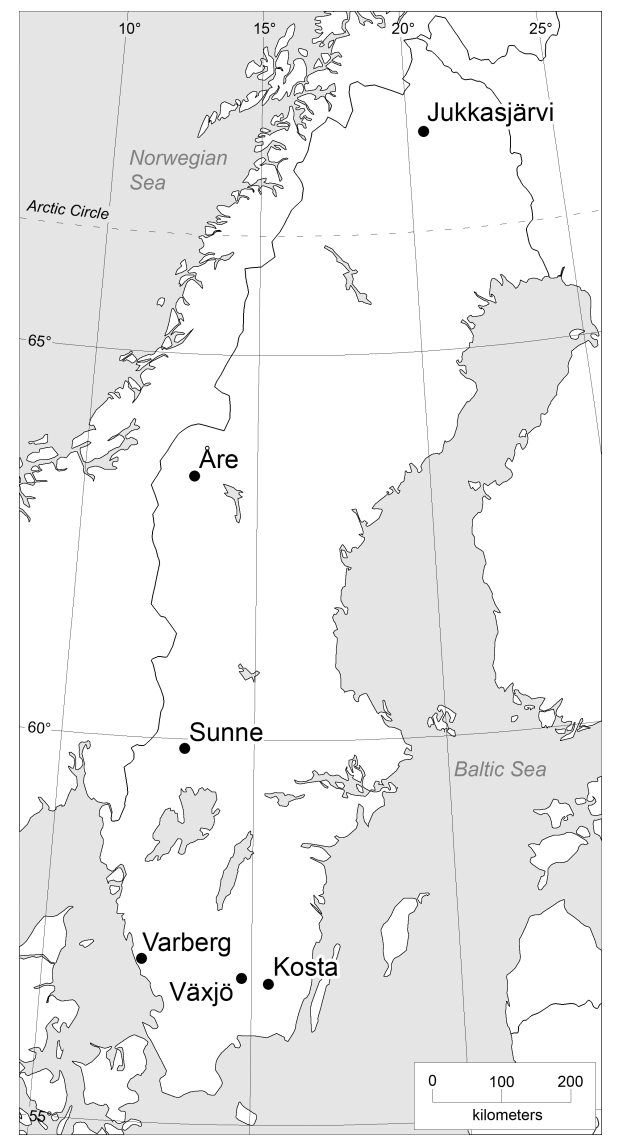




\begin{tabular}{|c|c|c|c|c|c|c|}
\hline & Data type & $\begin{array}{l}\text { Time for } \\
\text { collection }\end{array}$ & $\begin{array}{l}\text { Paper } 1 \\
\text { Literature } \\
\text { review }\end{array}$ & $\begin{array}{l}\text { Paper } 2 \\
\text { Flagship } \\
\text { hotels }\end{array}$ & $\begin{array}{l}\text { Paper } 3 \\
\text { Policy } \\
\text { tourism }\end{array}$ & \begin{tabular}{|l|} 
Paper 4 \\
Green place \\
branding \\
\end{tabular} \\
\hline \multirow[t]{2}{*}{$\begin{array}{l}\text { Secondary } \\
\text { data \& } \\
\text { sources }\end{array}$} & $\begin{array}{l}\text { Research literature } \\
\text { a) Place branding } \\
\text { b) Policy mobilities } \\
\text { c) Green policies }\end{array}$ & $\begin{array}{l}\text { Late } 2012 \text { (a), } \\
\text { Late } 2013 \text { (b), } \\
\text { Mid } 2014 \text { (c) }\end{array}$ & (a) & $(\mathrm{a}, \mathrm{b})$ & $(a, b, c)$ & $(\mathrm{a}, \mathrm{c})$ \\
\hline & Secondary sources & 1998-2014* & & $\mathrm{x}$ & $\mathrm{x}$ & $\mathrm{x}$ \\
\hline \multirow[t]{2}{*}{$\begin{array}{l}\text { Primary } \\
\text { data \& } \\
\text { sources }\end{array}$} & Interviews & $\begin{array}{l}\text { Early } 2011, \\
\text { Early } 2012, \\
\text { Early } 2014, \\
\text { Late } 2014\end{array}$ & & & $\mathrm{x}$ & $\mathrm{x}$ \\
\hline & $\begin{array}{l}\text { Participatory } \\
\text { observations }\end{array}$ & $\begin{array}{l}\text { Early } 2011, \\
\text { Early } 2014\end{array}$ & & & $\mathrm{x}$ & $\mathrm{x}$ \\
\hline
\end{tabular}

Table 2. Overview of the sources used in separate papers (*detailed numeric data provided by Växjö kommun have been collected from 1998 to 2014, myself I have collected secondary sources in 2012 and 2014).

Four papers are presented in this thesis. Combining different methods, all of the papers have a primarily qualitative methodological approach. An overview of the data used in the different papers is presented in table 2, and longer presentations of the papers are outlined in the next section. Papers 1 and 3 use a combination of quantitative and qualitative data; however, it should be noted that, with regards to the quantitative elements in these papers, they present descriptive statistics exclusively.

In paper 1, an in-depth literature review of place branding research published in human geography is presented, and the development of place branding in the research literature is analyzed over time. Here, the object studied is the conceptual understanding(s) of place branding in human geography and how it moves and mutates when combined with different theoretical approaches from the wider discipline of geography or when applied to different empirical settings.

Paper 2 discusses place branding in the form of flagship hotels. The concept of "follow the policy" (cf. Peck \& Theodore, 2012) has been approached by studying the implementation process of a single policy model (i.e., flagship hotels) in five different locations in Sweden, over time. This has required access to historical data available through different sources to "map" the development process of the five individual cases.

The interconnectedness between study visits and place branding in the form of policy tourism is analyzed in paper 3 , while paper 4 discusses the relationship between place branding and environmental policymaking. For both these papers, longitudinal data are employed to study a single case (i.e., Växjö) from two different policy perspectives related to place branding. Here, the empirical foundation is comprised of in-depth interviews and participatory observations from 2011 and 2014, and it is supported by secondary data that account for the historical development of policies in Växjö. By following the development of policies over time in a single place, the data provide a longitudinal perspective to the case study. It is argued that the temporal impacts on the relationship between a place and place branding strategizing are more easily detected than 
what is traditionally provided by a "snapshot" case study (Jensen \& Rodgers, 2001) that collects data at only one point in time. Additionally, by revisiting the same places, informants, positions and topics on different occasions, the reliability of the data is supported and the possibilities of evaluating the quality of the empirical sources are also improved.

\section{Secondary data $\&$ sources}

\section{Research literature}

Three main streams of the research literature have been reviewed within the frame of this thesis. These streams are place branding, policy mobilities and green policies. The reviews were conducted chronologically in that order, as presented in table 1.

A detailed description of the first review (on place branding) is presented in the methods section in paper 1. In short, this literature stream covers peerreviewed articles published in journals categorized as either 'geography' or 'urban studies' with the keywords 'city branding', 'destination branding' or 'place branding'. A total of 86 articles that were published between 2000 and 2012 were reviewed.

The motive for conducting the first literature review derived from the objective to address how human geographers research place branding. Triggered by a number of cross-disciplinary literature reviews from non-geographers (Berglund \& Olsson, 2010; Lucarelli \& Berg, 2011) that present sweeping accounts of how geographers view place branding, a structured analysis from within the discipline was necessary. Because the results of the analysis presented somewhat interesting findings that contrasted with previous published research, the literature review was transformed into a separate article (paper 1). Naturally, insights from the literature review inform this comprehensive summary as well as papers 2,3 and 4 .

The second literature review on policy mobilities stemmed from the repeated debate within place branding on the copying and borrowing of good branding ideas from one place to another, creating a 'copy-cat effect', with many places applying the same place branding strategies (Ashworth, 2009). The discussion revolves around the potential gains and losses entailed in learning about place branding from elsewhere (Currid, 2007; Klauser, 2011), and it touches on the wider discussion on policy mobilities and transfers.

Publications from three special issues of the journals Environment and Planning A (2012, vol. 44, No. 1), Geoforum (2010, vol. 41, No. 2) and Policy Studies (2012, vol. 33, No. 6) especially constitute the bulk of the literature reviewed and the literature stream on policy mobilities, with additional publications derived from the references used in these special issues. Beyond 
providing theoretical insights to papers 2 and 3, the second literature review resulted in a working paper that was presented at the Department of Human Geography at Stockholm University during the autumn 2013 (Andersson, 2013).

The third review on green policies was inspired by the place branding theme of the case study site Växjö. To arrive at a more thorough understanding of the actions and decisions taken in Växjö related to the local place brand, the analytical framework needed to be broadened beyond mere place branding. The ambition for green imaginaries (Anderberg \& Clark, 2013), the greening of local economies (Acuto, 2012) and the lessons provided by good examples (Gustavsson, Elander, \& Lundmark, 2009) presented many overlaps between the green policy literature stream and the wider conceptual discussion on place branding.

In paper 4, the results of the review on the green policy literature stream constitute the analytical framework used in the article. As with the two previous literature reviews, the main texts are collected from databases that include peer-reviewed articles and books. The findings from the third review also inform the analysis in paper 3, which also uses Växjö as a case study.

\section{Secondary sources}

The use of secondary sources has varied between the different papers (see table 4 above). In paper 2, the Swedish database Nordic Business Key (Bisnode) (formerly known as Affärsdata) has been the primary source of data. Bisnode presents detailed information on corporations operating in Sweden and newspaper articles of a commercial and industrial character from most national and local Swedish newspapers. The deployment of secondary sources in the study on place branding and policy boosterism, have been suggested by Pow (2014) as a source of 'critical insights' into how strategies and knowledge are re-produced within local administrations.

In the Bisnode database, the names of the hotels (the current and previous names) were used as keywords to search for newspaper materials and corporate information. More than 150 unique articles from both national (Dagens Nyheter, Aftonbladet, Dagens Industri, Svenska Dagbladet, Affärsvärlden) and local (Nya Wermlands Tidning, Östersundsposten, Smålandsposten, Hallands Nyheter, Norrländska Socialdemokraten, Norrbottenskuriren) newspapers were retrieved, read and analyzed. In addition, ownership histories and structures, economic turnover rates, figures on employment and the liquidity levels of the different hotels from various years were provided by the database.

In papers 3 and 4, the electronic archives of the local Växjö newspaper Smålandsposten and newspaper articles found through the Bisnode database have been extensively used both to establish a background knowledge of the local development process and to function as a "second" voice in relation to the accounts and testimonies provided by public officials. Keywords such as 
Sustainable Småland, Europas Grönaste stad (in English, "the Greenest city in Europe") and technical visits (the same terminology used in both Swedish and English) were used in the two databases. International news reports on the green policies of Växjö (available through the Växjö municipality webpage) have been added to the empirical data. Approximately 90 newspaper articles in total regarding Växjö have been read and analyzed.

Corporate and municipal homepages have also been a widely used source in articles 2, 3 and 4. With the principle of public access to official records in Sweden, the online availability of policy documents, strategy documents and meeting protocols is high, with no special access required to obtain such documents. Especially in paper 2, the availability of and level of detail in official records accessible online have been of crucial importance because no primary data were collected for this article.

For papers 3 and 4, public officers working within the Växjö municipality have been very generous in sharing memoranda, notes and other records from their personal catalogues and computers. From Sustainable Småland, I have most generously been offered login privileges to view webpages that are only available to the members of the network. In addition, official pamphlets, folders and other publications from the Växjö municipality, Sustainable Småland and other actors working with Växjö have completed the set of secondary data used in these articles.

With all secondary sources, the analysis has been conducted by focusing on how, why and by whom place branding policies are developed and discussed. In paper 2, this analysis was performed in relation to the wider discussion on flagship buildings and hotels (McNeill \& McNamara, 2009; McNeill \& Tewdwr-Jones, 2003), and in papers 3 and 4, with policy boosterism (McCann, 2013) and green policy development (cf. Emelianoff, 2013) in mind.

For paper 3, the Växjö municipality has most generously provided statistical data regarding technical visits to Växjö. Public officers working with technical visits have collected the data annually since 1998, and the last available records are from 2014. The purpose of the data collection is internal reporting on the development of these visits. However, due to changes in the organization of technical visits (see paper 3 ), the level of detail in the data varies across different years, which is highlighted in that paper as appropriate.

Descriptive statistics on the number of visiting groups, country of origin, number of paying groups, policy field of interest and occupations of visitors have been analyzed more closely. To enable a multi-level analysis, the different statistical datasets from each year have been compiled and codified in a single document by the first author of paper 3 . 


\section{Primary data \& sources}

The primary data have a longitudinal character, meaning that they have been collected over the course of several years. Two main periods of data collection have taken place during the writing of this thesis, early 2011 and early 2014.

\section{Interviews}

Two types of interviews were conducted, semi-structured in-depth interviews and short unstructured interviews for use in papers 3 and 4. All interviews took place face-to-face, except one semi-structured interview that was conducted over the telephone with an informant who had participated in several previous face-to-face interviews. The in-depth interviews followed a preformulated structure of questions, with room for the informant to more freely elaborate on the issues discussed and allowing spontaneous follow-up from the interviewer. The in-depth interviews were all recorded and then transcribed. All of the interviews took place in the premises of the informant's work (office or adjacent conference room) and took 30-60 minutes. A total of 16 in-depth interviews were conducted.

The informants were mainly public officers working within the Växjö municipality or people who had previously held such positions. Three interviews were conducted with elected politicians in Växjö, and one interview was conducted with an international policy expert working for ICLEI. The selection for the 2011 interviews was based on so-called "snowballing" (Flowerdew \& Martin, 2005), where the Chief Information Officer in Växjö was contacted first, and then additional contacts were made with other informants on the Chief Information Officer's recommendation. The choice of snowballing was motivated by an ambition to find the underlying social structures and networks of relevance for the development of place branding. During the 2014 interview rounds, two follow-up interviews were conducted with people who had been interviewed in 2011, and the remaining informants were contacted directly based on their job assignment and prior knowledge of the case study.

The 2011 interviews were conducted with an "exploratory approach" (Ritchie, Lewis, McNaughton Nicholls, \& Ormston, 2014), focusing on the place brand "the Greenest city in Europe". Three years later, the scope of the interviews was both more focused and more widened. In 2014, the interviews incorporated the branding of Växjö as a green city alongside the development of technical visits and a more general green policy development.

In addition, several shorter follow-up interviews (5-15 minutes) with previous informants were conducted after meetings or technical visits. Additionally, short interviews with people visiting Växjö through these technical visits were also conducted during the field trips or coffee breaks. These short interviews were not recorded or based on pre-formulated questions; instead, they were more "topical interviews" (Ritchie et al., 2014) that focused on the im- 
pressions and experiences of the field trip, meeting or workshop in which we both had participated. With these shorter interviews, brief notes were scribbled down afterwards, and longer notes were taken as soon as possible without making the informant feel like a "study object".

The informants participating in the interviews have not been promised anonymity. Due to the relatively small group of people working in the Växjö municipality, it would be impossible to keep such a promise. A complete overview of the names and titles of informants can be found in Appendix 1. However, it should be noted that the informants have been interviewed in their professional capacity, not as private citizens. For the short interviews, no names of the interviewees have been recorded. Despite not having promised anonymity to the informants, no given names are presented in papers 3 and 4 in connection to direct citations or statements. Instead, the person's professional function is presented to maintain a certain distance between the readers of the articles and the informants.

The interview data have been analyzed based on different themes - place branding, technical visits, green policies - and categorized accordingly. For paper 4, the official narrative on green Växjö has been crystallized by analyzing the repetitive background stories presented at technical visits (see below) and during interviews with different informants giving similar accounts to the developments in Växjö, in combination with the written materials presented in pamphlets, presentation materials and newspaper stories.

\section{Participatory observations}

To complement the primary data collected through interviews, a number of participatory observations were conducted. The main aim of these observations was to study "policy work in action", including how it changes over time. The format of the observations varied greatly, from attendance at board meetings with only a handful of participants to large meetings with over 100 participants. My role as an observer and the reason for my presence were made public to all participants by the organizer of the events in all meetings except one (a breakfast meeting with a compact agenda). To accompany the observations, photos and notes have been taken as appropriate.

In the smaller social settings, notes and photos were not taken to avoid creating a feeling of being observed among the meeting participants. Immediately after such observation sessions, notes and comments were recorded. In the larger social settings, notes were written down more freely during the meeting, given that my presence was less noticeable. In total, I participated in 4 different meetings during these observations during 2011 and 2014.

Participatory observations were also made during four days of technical visits. In these visits, I participated with the visiting group in different study tours, workshops, or luncheons. following the program of the visit. During the technical visits, a public officer working in Växjö made my presence as an 
observer known to all participants at the welcoming address of the visits. During walks, bus rides and coffee breaks, I talked to the visitors about their experiences and the expectations they had for their visit to Växjö (see short interviews above). Because the visiting groups were somewhat large (25-60 people), I took notes and photos as appropriate (see figure 3 below) ${ }^{1}$.

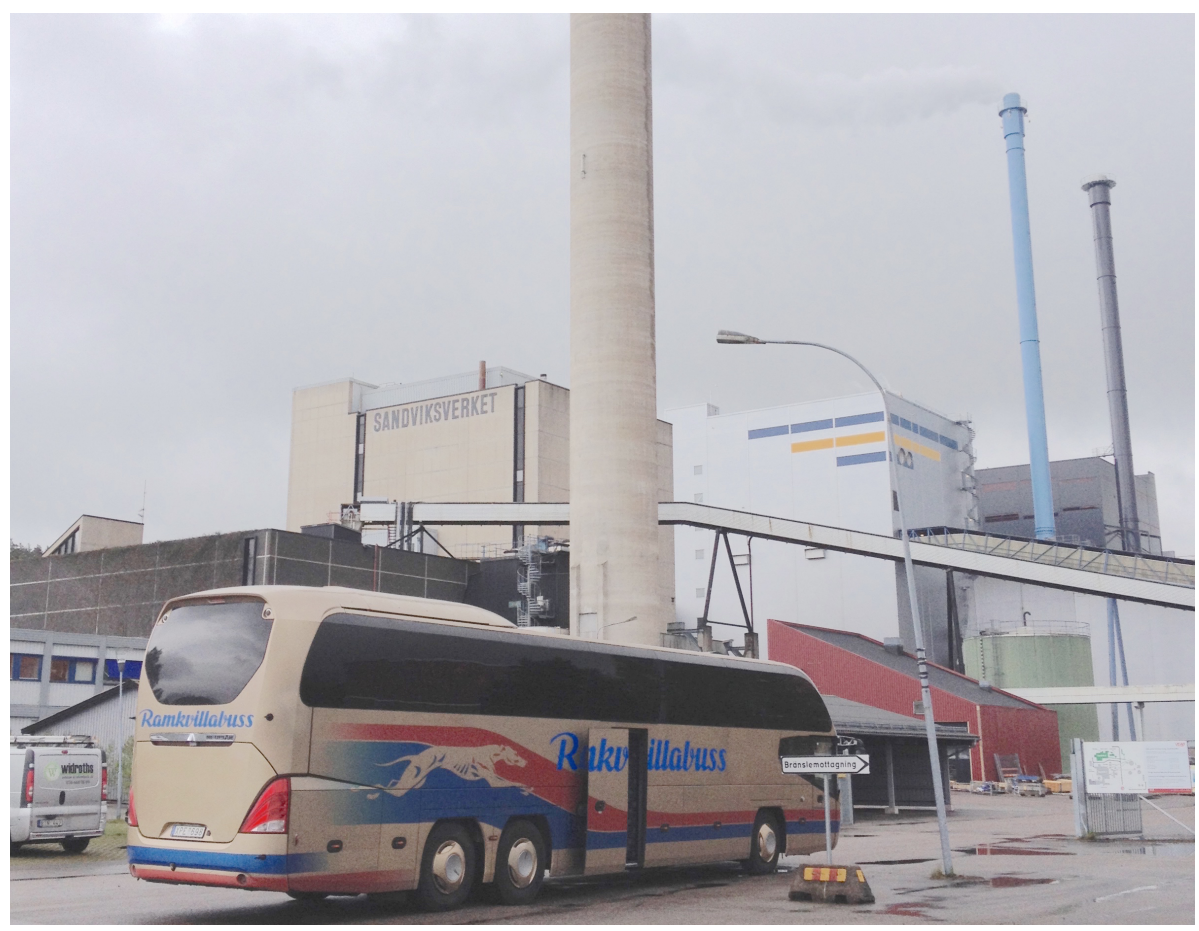

Figure 3. Photo showing tour bus outside Sandviksverken, the local power plant in Växjö, during a technical visit in May 2014 (photo by author).

Being an observer, I chose a passive and silent approach in my observations. However, I participated in related activities when asked or invited to do so. To transport myself to the different sites during study tours, riding an electrical bike together with informants or traveling in one of the municipality's electrical cars together with the informants was an element of the observational study with a more social and interactive character.

As a consequence of the longitudinal character of the primary data collection, certain social relationships beyond traditional researcher-informant relations developed between a handful of the informants and myself. By interviewing the informants and participating in meetings and technical visits to-

\footnotetext{
${ }^{1}$ Due to temporary security issues with the construction of Sandvik 3 inside the plant and the visiting group's size ( $>60$ people), we were not allowed inside the premises on the day of the photo. Instead, a one-hour presentation was given inside the bus outside the plant by one of the project managers working at the plant.
} 
gether with them over a longer period of time, small talk over coffee and lunch provided me with details on the processes at play that would not have been accessible through formal interviews only. For me as a researcher, this social interaction could pose a potential problem for the analysis of the data if I let personal opinions and judgment interfere with the review of the data. However, by combining primary and secondary data to follow the policy processes in Växjö, the risk of being biased by personal accounts and social relationships is reduced.

A complete list of the meetings and technical visits in which I participated as an observer can be found in Appendix A. 


\section{Structure of thesis and summary of papers}

The structure of this thesis to a large extent followed the trajectory of how my research work was conducted. With the objective of contributing to the geographical understanding of place branding, a natural starting point was to engage in a detailed understanding of what research work had been carried out. This investigation laid the foundation for paper 1, which presents an in-depth literature review on place branding research in human geography. The findings from this paper informed both the design and formulation of research questions for the additional three papers and the design and conceptualization of this comprehensive summary. Further, the research work and findings from the three empirical papers (2-4) also affected this comprehensive summary and the understanding of the findings in paper 1, as illustrated in the figure below.

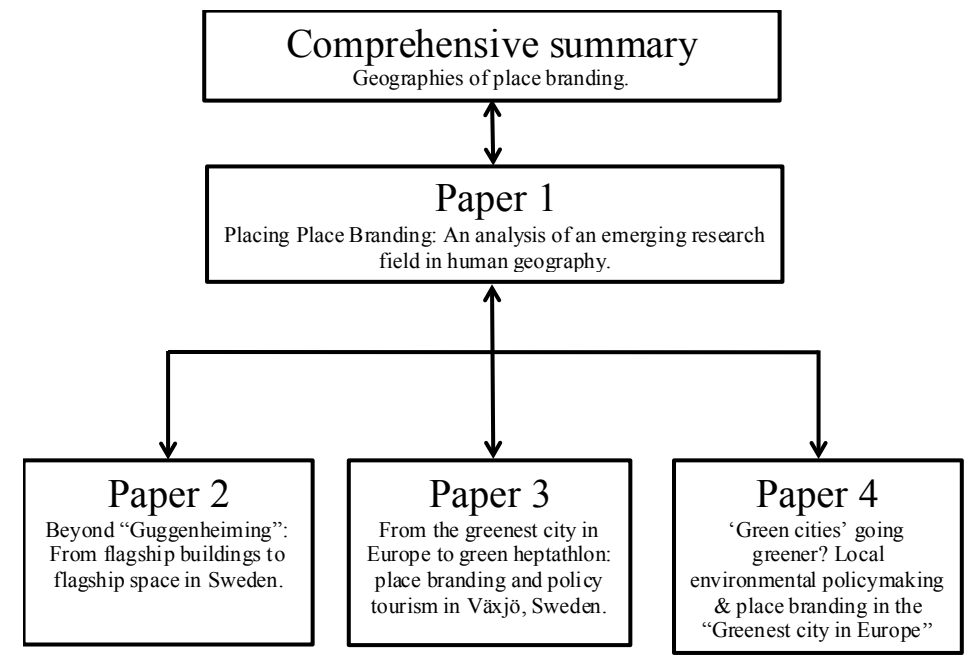

Figure 4. Structure of thesis (source: author).

The four papers presented below all have individual formulations of research aims and questions that provide insights into various aspects of place branding. Taken together, they aid in fulfilling the overarching aim of this thesis, specifically, to contribute to the geographical understanding and research practice of place branding. Guided by the conceptual framework, the concluding discussion following this summary will discuss the aspects of territoriality 
and relationality of place branding advanced through this research and briefly relate to the more detailed findings in each of the individual papers.

\section{Paper I: Placing place branding: an analysis of an emerging research field in human geography}

Inspired by recent scholarly discussions on the geographical dimensions of place branding, including several recently published cross-disciplinary literature reviews, this paper presents an in-depth analysis of place branding research published in human geography. A total of 86 research articles published in human geography from 2000 to 2012 were analyzed. On the basis of this analysis, the paper makes three claims: first, it is time for place branding research to move beyond a conceptual understanding of place branding as the adaption of corporate branding to places. Second, in human geography, place branding research is primarily empirically based, which can be seen as an argument against the previous claims of scarce empirical basis for the theoretical claims made in place branding studies. Third, by using perspectives and theories from human geography in the study of place branding, it is argued that geographers make distinctive conceptual contributions to the research field of place branding.

The literature analysis is divided into two sections, a quantitative section and a qualitative section. The quantitative findings of the literature analysis illustrate how the empirical research has a strong overrepresentation of qualitative studies that combine two or more methods and that are primarily concerned with large cities and capitals located in Europe, Asia and North America. Therefore, one of the conclusions of the paper is to suggest that the current research field contains several "gaps" in terms of methodological approaches, scale and geographical locations with regards to empirical studies in place branding.

The qualitative findings presented in the paper suggest that there are seven distinct perspectives in the human geography research on place branding. These perspectives are the following: (1) place identities and place images, (2) urban entrepreneurialism, (3) the theoretical relationship between branding and geography, (4) place branding practices, (5) democracy and social exclusion, (6) creative places and (7) geographical co-branding. Each of these perspectives is connected to other well-established research approaches in human geography, thus drawing on different concepts and frameworks in their examinations of place branding. In conclusion, joining the quantitative and qualitative findings together, this paper suggests that place branding research has moved beyond a routine conceptualization of corporate branding to places out into a wider understanding of interplaying societal, political, spatial and economic structures that create what is known as place branding. 


\section{Paper II: Beyond "Guggenheiming": From flagship buildings to flagship space in Sweden}

In this paper, a case study of five flagship hotels located in small towns in Sweden is presented. Together, the five hotels are considered to be "best practice" within their respective genre, focusing on offering visitors different cultural, adventurous and relaxing experiences through providing art exhibitions, outdoor activities and spas. Using a conceptual framework that presents a 'territoriality-relationality symbiosis' of flagship hotels, the paper illustrates how so-called best practice flagship hotels have developed over time.

The paper argues for a dualistic understanding of flagship buildings that acknowledges both the relational and territorial dimensions of such developments. Using the famous "Guggenheiming" policy model as reference (referring to the cultural development strategies implemented in Bilbao, Spain), this paper illustrates how there is an overly relational perspective in the place branding academic debate on flagship buildings. As a key tool in place branding and a popular object to "copy and borrow" among policy makers, the study of flagship buildings joins together streams of literature from place branding and policy migration.

When analyzing the case studies, it becomes clear that the flagship hotels have emerged through the interplay of both territorial and relational processes. These processes involve both local and global policy and investment networks; territorial path dependencies, strong entrepreneurs with territorial connections carrying relational ideas; and windows of opportunity that have facilitated the development of the hotels locally. In addition to these processes, the development of the hotels' flagship status has been aided by the active involvement of actors outside the hotel management. A wide range of entrepreneurs, organizations, policymakers and community representatives contribute to the process of producing and reproducing the hotels' flagship status, changing the spatial dimension of the flagship from the hotel itself to incorporate a wider geographical area.

Therefore, the main conclusion of this study is that the development of the hotels is connected with both territorial and relational geographies, thus presenting an understanding of these hotels as not merely flagship buildings but rather as creators of flagship space.

\section{Paper III: From the greenest city in Europe to green heptathlon: place branding and policy tourism in Växjö, Sweden (Co-authored with Laura James)}

This is the first of two papers in this thesis that study place branding in Växjö, a medium-sized city in south-east Sweden that is branding itself as the 
"Greenest city in Europe". In this paper, place branding in Växjö is discussed in the context of "policy boosterism" and "policy tourism".

In recent years, the increased mobilization of urban policy, attributed to processes of globalization and intra-urban competition, has been identified. One consequence of this development is the emergence of certain 'celebrity' cities that have become 'models' of particular urban policies. Such cities have become privileged nodes in the global networks through which policies circulate. By studying successful examples, policymakers hope to be inspired by the 'best' policies from such cities and to import them for implementation in a new context back home. Through this process, fact-finding trips undertaken by policymakers to various policy destinations have become a common feature in contemporary urban policymaking.

However, from the celebrity cities' perspective, we know little about why they choose to help others to successfully copy their policies and programs. Most studies within the policy mobilities literature have 'followed the policy' - concentrating on the circuits and processes through which policy models travel and mutate - rather than focused on the motivations of the coalitions of actors in 'host networks'. Our aim in this paper is to address this gap and show how the motivations of the celebrity cities attempting to brand themselves on the basis of their public policies evolve over time. The paper draws together streams of literature on policy boosterism, policy tourism, and place branding to explore the motivations of cities sharing policies in a competitive policy environment through policy tourism.

Using the case of environmental and urban sustainability policies in Växjö, Sweden, we examine how the rationale for sharing policy has changed over time, both reflecting and shaping the organization of policy tourism through technical visits and the branding of Växjö as 'the greenest city in Europe'. Our study suggests that policy tourism and urban policymaking co-evolve in the context of policy boosterism and place branding. In Växjö, what began as opportunistic branding now drives local environmental policymaking as the city strives to remain at the cutting edge. We suggest that detailed, longitudinal case studies are necessary to construct a picture of the relationship between policy boosterism, policy tourism and urban policymaking in a variety of contexts.

\section{Paper IV: "Green cities" going greener? Local environmental policymaking and place branding in the "Greenest city in Europe"}

This is the second paper in this thesis that presents data that was collected in research conducted in Växjö. Positioned in a context where a growing number of cities around the world have taken advantage of their green image for the 
purpose of place branding, this paper discusses the relationship between green public policies and place branding over time. In the research literature on green cities and place branding, it is suggested that these practices are motivated by place-based competition over financial and social capital combined with more holistic motives of sustainable urban development. However, although an increasing number of green cities engage in place branding, few studies have researched how the turn towards green place branding impacts on the continued environmental policymaking in a city. What happens to local environmental policymaking when a framework of place branding embraces it?

Addressing this issue, this paper analyzes how the continuity of local environmental policymaking is affected by place-branding practices. To accomplish this task, the paper first introduces an analytical framework of the elements in environmental policymaking that have been identified as generating a green status for cities. Through a literature review on green cities, an analytical framework is presented that describes six policy elements and how they function. The six policy elements are as follows: (1) historical events, (2) selective policy definitions, (3) funding programs and public investments, (4) extra-local policy networks, (5) localized networking and alliances, and (6) imagineering and identity.

Second, using that framework, this paper presents an in-depth case study of Växjö as it brands itself as the "Greenest city in Europe". By studying the development of these policy elements before and after the launch of the green place brand in Växjö in 2008, the paper reveals an intricate relationship between green city policies and place branding. The main findings suggest that green city policies and practices transform over time, adapting to both changes in the local milieu and external pressures. Place branding adds different types of pressures to such policies, introducing new sets of stringencies that are related to maintaining brand promises. Simultaneously, however, place branding broadens the scope of green practices by questioning the definition of what counts as a green in green place branding. 


\section{Concluding discussion}

The point of departure for this thesis is a call for a re-conceptualization of place branding, for which a geographical/spatial approach has been employed. Here, I advocate an understanding of place branding as the application of branding in places, rather than to them, emphasizing the multidimensional and transformative characteristics of place in place branding.

The explicit aim of this thesis is to contribute to the geographical understanding and research practice of place branding by accomplishing three different tasks that are addressed below.

\section{Task 1: Introduce and discuss a conceptualization of place branding from a geographical perspective}

This thesis has illustrated how place branding is much more than merely the migration of corporate branding theories and strategies to places. Instead, place branding practices are the effect of interrelated and interdependent place-based processes that to some extent have been shaped and designated by corporate branding rhetoric. Mainstream place branding theory presents certain sets of ideas and connects places with each other through a discourse of inter-urban competition, which in turn imposes organizational policies on places. Public-private partnerships, localized networking and international connectedness through policy networks are some of the organizational traits of place branding in places. Simultaneously, branding seems to increase collaboration and learning between places because sharing 'best practice' is advised among local governments, which may be regarded as counterproductive to place competition and the struggle to stand out in an "increasingly crowded marketplace" (Hannigan, 2003: 352) through place branding.

Paper 1, which presents seven distinct research perspectives applied by geographers in the study of place branding, illustrates how a reconceptualization of place branding is already underway in the field of human geography. Paper 2 addresses the re-conceptualization of place branding by deconstructing the conceptual and spatial assumptions of flagship buildings, one of the most common and established tools for place branding. The paper illustrates how flagship buildings are developed in the interplay between rela- 
tional and territorial processes, transcending the understanding of flagship buildings by casting them as producers of flagship space.

The two remaining papers tackle the task of re-conceptualization by addressing one of the fundamental concepts of place branding, i.e., place-based competition. In paper 3, the motives of receiving policy tourists are investigated, and the results show that the motives for hosting study tours vary over time, are connected to the place's brand status and credibility as "green" and are not compromised by place-competition argumentation. Instead, more practical and organizational reasons guide the hosting of policy tourism. In paper 4 , it is argued that "green place branding" imposes new economic and organizational rationales on environmental policymaking and that the main motives for adopting a "green" place brand seems to be both accidental and pragmatic. Instead of leaning on arguments of place-based competition, place branding here seems to be a method for local governments to organize their work and to establish a community feeling.

\section{Task 2: Apply and discuss a number of methods on how to research place branding from a geographical perspective}

When setting out to engage in a re-conceptualization of a research domain, it is not enough to merely articulate a few "new" ways of thinking about this research. It also involves presenting suggestions on how to conduct research that adopts these perspectives. Thus, addressing this second task of the thesis, the four papers contribute to this endeavor in slightly different ways. With the quantitative review performed in paper 1, we have learned that most geographers already do what Pike (2011a) has suggested, i.e., applying a mixedmethods approach to the study of place branding.

With an emphasis on qualitative interviews, most geographers use a range of traditional methods employed in geography, including various observational techniques, surveys and focus groups when researching place branding. The widespread use of mixed-methods approaches has also been identified in the place branding research domain from a cross-disciplinary perspective (cf. Lucarelli \& Berg, 2011). However, as the examples below illustrate, there is still much to add to the mixed-methods repertoire of place branding research, and above all, it is important to connect these methods to the wider geographical perspectives of territoriality and relationality:

First, as all three empirical papers demonstrate, adding the perspective of time to the study of place branding can provide new, and seemingly understudied, dimensions of the phenomena. By focusing on the historical development of place branding, nuances and aspects of both territorial and relational origin emerge that situate place branding practices in a wider spatial contex- 
tualization. For example, the historical dimensions and the impact of path dependency are vital to the understanding of both the development of the flagship hotels and the "green place branding" of Växjö. Without the temporal aspect included in the analysis, these cases would come across as traditional "best practice" case studies that add few new insights to the field and at best contribute to "a 'serial reproduction' of their own - one producing new case studies of slogans and strategies without furthering conceptual understandings" (McCann, 2009: 123).

Second, in this thesis, I have elaborated my arguments with the use of secondary sources, both in conjunction with primary data collection and as a standalone method. By relying on local newspaper materials and business reports, paper 2 illustrates how the "mapping" and "following" of several different local developmental histories can provide a foundation for a comparative analysis of different place branding cases. As noted by several scholars, the shortage of comparative analyses has been viewed as a gap in the current place branding research. Additionally, the use of newspaper materials and other secondary sources can provide a "second" voice in understanding the local development of place branding, circumventing the risk of collecting place branding narratives solely from primary sources. In addition, secondary sources may also complement the study of place branding from a time-based perspective, given that many newspapers and libraries provide easy access to electronic archives.

Third, several researchers have suggested that a greater methodological focus should be placed on the agents of branding (cf. Pike, 2011a; Warnaby et al., 2015) to aid in the re-conceptualization of place branding. In this thesis, this methodological challenge has been addressed by researching place branding in small and medium-sized cities. This perspective not only facilitates the detailed study of place branding agents and their interconnectivity but also provides relatively easy access to the many layers of territorial and relational processes involved in place branding. In small and medium-sized cities, the number of agents is lower, the networks are smaller and the external linkages are easier to identify compared to larger cities and capitals. It is not suggested that all future place branding research should be conducted in small and medium-sized contexts only but rather that these smaller scale case study areas have the potential to function as "test labs" for future conceptualizations on the subject. 


\title{
Task 3: Highlight and address a gap in the research literature, by researching place branding through small and medium-sized cities
}

Identified as an under-explored field of research and a potential gap in the geographical understanding of place branding in paper 1, papers 2,3 and 4 have had an explicit focus on place branding in small and medium-sized cities. Overall, these three papers illustrate that the processes of place branding that take place in these "smaller size" case studies to some extent resemble the processes of place branding found in "large size" case studies in previous research. For instance, the development of flagship hotels in five small towns in Sweden bears similarities to the general understanding of how flagships are expounded, based on the lessons learned from large cities and global metropolises. Similarly, the processes related to policy tourism and the development of "green place branding" in Växjö share many commonalities with the experiences from considerably larger and more globally connected cities such as Barcelona (Gonzalez, 2013), Vancouver (McCann, 2013) and Copenhagen (Anderberg \& Clark, 2013).

However, by focusing on small and medium-sized cities, the relationality and territoriality of place branding becomes emergent and tangible. As all three empirical papers have shown, the processes of place branding take place with a strong connection to local traditions and prerequisites (i.e., territorial processes), such as path dependencies and local resources; simultaneously, they are highly extra-locally networked and globally connected (i.e., relational processes). Through the interactions between investment flows and ownership structures, political management, local windows of opportunity, policy networks, visitor flows, policy hubs, path dependencies and media reporting, local place branding becomes a collaborative effort between local actors and structures that work together with non-local stakeholders and flows. This is the situation for both large cities and capitals as well as small and mediumsized cities. However, in "smaller size" case studies, these networks and processes are more easily detectable and reviewable.$$
\infty
$$

In conclusion, the re-conceptualization of place branding through the lens of geography is argued to add many new layers to the understanding of this expanding research field. By treating place branding as a spatially empirical phenomenon rather than a corporate theoretical concept, wider conceptual considerations can be made by reflecting on the geographies of place branding. Ultimately, perhaps the lack of "a clear and commonly accepted theoretical framework" (Ashworth et. al, 2015: 2) and "a need for tighter specification
\end{abstract}


of the concepts" (Hankinson, 2015: 27) are not the main challenges for this expanding research domain going forward?

After all, instead of attempting to compress the conceptualizations and definitions of place branding together into "a consensus of agreed theory" (Warnaby et al., 2015: 242), I would like to suggest the opposite. In unpacking and following place branding practices on the local level, it becomes evident that place branding is the result of many different aspects of territorial and relational processes. Therefore, I suggest, that the task at hand for researchers pursuing this re-conceptualization of place branding is to develop a number of different conceptual tools and perspectives that together can aid in understanding the many different and continuously transformative geographies of place branding. 


\section{Svensk sammanfattning (summary in Swedish)}

Platsmarknadsföring (på engelska: place branding) porträtteras ofta genom exempel från välkända och stora städer, så som London, New York och Singapore. Som en kontrast till detta sätts i den här avhandlingen små och medelstora orter i fokus och syftet är att studera platsmarknadsföring utifrån ett geografiskt perspektiv.

Avhandlingen har sin utgångspunkt $\mathrm{i}$ en diskussion om den teoretiska och empiriska förståelsen av platsmarknadsföring; vad det är och hur det påverkar de platser där marknadsföringsaktiviteter genomförs. Det finns en seglivad tradition bland såväl forskare som praktiker att slentrianmässigt definiera platsmarknadsföring utifrån marknadsföringsprinciper och modeller som tilllämpas för produkter och företag. Detta sätt att se på platsmarknadsföring börjar emellertid i allt större utsträckning ifrågasättas av forskare verksamma inom olika ämnesdiscipliner och forskningstraditioner. I korthet kan denna kritik delas in i två kategorier, dels en där man hävdar att förståelsen för marknadsföring är bristfällig, och dels en kritik främst representerad av forskare i geografi och som menar att förståelsen för plats är undermålig. Gemensamt för dessa båda kritiker är att den nuvarande förståelsen av platsmarknadsföring som används inom både forskning och praktisk tillämpning inte kan på ett tillfredställande sätt förklara och förstå den rumsliga praktik som platsmarknadsföring innebär.

Då tidigare försök till att utveckla ny konceptuell förståelse av platsmarknadsföring framförallt har vänt sig till marknadsföringsteori, ger sig denna avhandling i kast med att diskutera hur den förståelsen av platsmarknadsföring kan utvecklas från ett platsteoretiskt perspektiv. Utifrån detta resonemang ställs denna övergripande fråga i avhandlingen: Hur kan mer rumsligt orienterade förståelser av platsmarknadsföring introduceras och hur kan dessa bidra till att forskningen om platsmarknadsföring blir mer relevant? Med utgångspunkt i denna frågeställning har avhandlingens syfte formulerats. Syftet med denna avhandling är att bidra till den geografiska forskningen om platsmarknadsföring genom att presentera djupgående fallstudier om platsmarknadsföring som utvecklats vid små och medelstora orter i Sverige.

I avhandlingen presenteras fyra artiklar vilka tillsammans bidrar till att besvara avhandlingens övergripande syfte och frågeställning. Den första artikeln presenterar en forskningsöversikt om hur platsmarknadsföring har studerats 
inom kulturgeografin. Analysen baseras på en granskning av 86 artiklar som publicerats i vetenskapliga tidskrifter mellan år 2000-2012. Artikeln är uppdelad i två delar, en kvantitativ del och en kvalitativ del. I den kvantitativa delen presenteras forskningsfältets utveckling över tid, vilka geografiska områden och platser som studerats samt vilka metoder som använts i forskningen. Resultat av denna analys ger en översikt över den geografiska forskningens inriktning vad gäller studier om platsmarknadsföring och visar att det finns ett antal geografiska och metodologiska kunskapsluckor i den befintliga forskningslitteraturen. Den kvalitativa delen visar att det finns sju olika teman som kulturgeografisk forskning om platsmarknadsföring har inriktat sig på. Dessa teman är: (1) platsidentitet och platsimage, (2) urbant entreprenörskap, (3) det teoretiska förhållandet mellan marknadsföring och geografi, (4) praktiker inom platsmarknadsföring, (5) demokrati och social exkludering, (6) utvecklingen av kreativa platser och (7) marknadsföring genom geografisk association. Sammantaget visar denna artikel att den konceptuella förståelsen för platsmarknadsföring inom kulturgeografisk forskning redan har flyttat bort från ett traditionellt teoretiskt ramverk från företagsekonomi och marknadsföringsteori. Istället fokuserar geografer på att analysera de sociala, politiska, rumsliga och ekonomiska strukturer och platssammanhangen som i samverkan skapar det vi idag förstår som platsmarknadsföring.

Den andra artikeln handlar om fem hotell belägna i fem mindre orter i Sverige. De studerade hotellen är: Ishotellet i Jukkasjärvi, Holliday Club i Åre, Selma Spa i Sunne, Kosta Boda Art Hotel i Kosta samt Varbergs Kurortshotell i Varberg. Gemensamt för dessa hotell är att de inom sina respektive tematiker och erbjudanden anses vara vad som på engelska kallas "best practice". Hotellen utgör också ett slags lokala flaggskeppsbyggnader (på engelska: flagship buildings) i de orter där de är lokaliserade. Hotellen erbjuder sina gäster olika typer av kulturella, äventyrliga och avkopplande upplevelser genom att tillhandahålla exempelvis konstutställningar, sport- och utomhusaktiviteter samt spa-behandlingar. Artikeln utvecklar och använder sig av en teoretisk modell som kallas "den territoriella-relationella symbiosen". Denna beskriver förhållandet mellan territoriella och relationella geografier och hur dessa samverkar genom flagskeppsbyggnaders tillblivelse och för den vidare utvecklingen som dessa projekt kan bidra till.

Med hjälp av denna modell om den territoriella-relationella symbiosen visar artikeln hur forskningen om flaggskeppsbyggnader inom platsmarknadsföring i hög grad primärt betonat ett relationellt perspektiv. I artikeln argumenteras att territoriella aspekter inte tilldelats tillräcklig uppmärksamhet. Territoriella aspekter är viktiga element bakom hur flaggskeppsbyggnader uppkommer och utvecklas. De huvudsakliga slutsatserna i artikeln är att hotellens utveckling kan kopplas till både territoriella och relationella geografier. Utifrån detta föreslås även att hotellen inte längre ska förstås som flaggskeppsbyggnader, utan istället som skapare av lokala flaggskeppsmiljöer. Dessa miljöer finns 
både i och utanför hotellen och tillsammans skapar de en förståelse av hotellen som "best practice".

Den tredje artikeln handlar om inkommande besökare till en kommun avseende studieresor och hur detta är en del av platsmarknadsföring och integrerat i kommunalt policyarbete. I artikeln studeras Växjö, som varje år tar emot ett stort antal internationella studiebesök. Dessa studiebesökare är politiker, tjänstemän och journalister som vill komma till Växjö för att lära sig mer om hur det lokala miljöarbetet går till och varför kommunen valt att marknadsföra sig som "Europas Grönaste stad". I forskningen om internationella studiebesök, som också kallas policy turism, finns mycket skrivet. Detta handlar om vad besökare som reser på den här typen av studieresor är intresserade av att lära sig och vilka kunskaper det är som de tar med sig hem. Däremot finns det nästan ingen forskning som undersöker varför en stad som använder sitt lokala policyarbete i marknadsföringssyfte vill dela med sig av sina kunskaper och strategier till andra potentiella konkurrenter.

I artikeln används forskningslitteratur om både policy turism och platsmarknadsföring baserad på politiskt policyarbete (på engelska: policy boosterism). Analysen visar att motiven till att ta emot och erbjuda studiebesök i Växjö kommun har varierat över tid och i relation till hur kommunen marknadsfört sig. I studien har 3 olika tidsperioder och teman identifierats internationalisering, kommersialisering och samverkan. De olika politiska och ekonomiska motiven till att ta emot och arrangera studiebesök kan sammankopplas med det lokala arbetet att marknadsföra Växjö och kommunens status som en föregångare inom miljöfrågor. I tillägg till denna slutsats föreslår författarna även att framtida studier på liknande teman bör studeras med ett longitudinellt perspektiv, för att blottlägga hur sammanlänkningar och ömsesidiga beroenden som finns mellan policy turism och policy boosterism över tid.

Den fjärde artikeln handlar om "grön" platsmarknadsföring, det vill säga platsmarknadsföring där en plats framhålls med hjälp av retorik om hållbar utveckling och miljöfrågor. I ett globalt perspektiv är det allt fler städer som har börjat positionera sig som "gröna", "hållbara" och "ekologiska" i marknadsföringssyfte. Flera tidigare forskningsstudier diskuterar varför städer väljer att göra detta och om dessa städer kan anses leva upp till de miljömässiga målen som utlovas. Den här artikeln tar sig an detta tema ur ett annat perspektiv och ställer frågan: hur påverkas det lokala miljöarbetet när det innesluts av platsmarknadsföring och hur kan den problematiken studeras? Artikeln är uppdelad i två delar; den första delen presenterar ett analytiskt ramverk med 6 olika policyelement som i samverkan bidrar till att skapa gröna städer. Dessa är: (1) historiska händelser, (2) selektiva policydefinitioner, (3) investeringsprogram och offentliga satsningar, (4) externt uppkopplade policynätverk, (5) lokala nätverk och allianser, samt (6) föreställningar och identiteter.

Den andra delen tillämpar det analytiska ramverket genom en fallstudie av Växjö och som behandlar relationen mellan det lokala miljöarbetet och platsmarknadsföring. För studien upprättas en tidslinje uppdelad i före och efter det 
att Växjö lanserade sitt platsvarumärke "Europas Grönaste stad". Analysen visar att det lokala miljöarbetet blivit mer strategiskt integrerat och samtidigt föremål för nya målsättningar och mätpunkter genom marknadsföringsarbetet jämfört med tidigare. Innan platsvarumärket existerade var det lokala miljöarbetet styrt utifrån de politiska och klimatmässiga ambitioner som fanns lokalt, vilket resulterat $\mathrm{i}$ ett fokus på att minska koldioxidutsläpp och reducera användningen av fossila bränslen. Efter att grön platsmarknadsföring introducerats i Växjö har det lokala miljöarbetet även omfattats av ett konkurrensperspektiv, där det inte längre handlar om att endast genomföra insatser som är bra för miljön utan även är bättre än vad andra städer redan har genomfört. Genom marknadsföringsarbetet har miljöfrågor i Växjö också fătt ett mer holistiskt perspektiv, där fler aspekter än bara koldioxidutsläpp och fossila bränslen inkluderats, och fler aktörer än bara lokala politiker och tjänstemän engagerats i miljöarbetet.

Sammantaget så har den här avhandlingen försökt att bidra att visa komplexa och ständigt föränderliga rumsliga strukturer som påverkar hur platsmarknadsföring uppkommer och utvecklas. Avhandlingen har också utvecklat modeller och metodexempel på hur platsmarknadsföring kan studeras ur ett geografiskt perspektiv samt lyft fram hur studier i små och medelstora städer kan vara relevanta för forskningsämnets fortsatta utveckling. Slutligen adresseras också ett av platsmarknadsföringens påstådda teoretiska tillkortakommanden, nämligen att det saknas ett gemensamt och sammanhållet konceptuellt ramverk. I kontrast till detta är en viktig slutsats från denna avhandling att en ökad diversitet och konceptuell mångfald är vägen framåt. I detta sammanhang är det framföralt platsmarknadsföringen geografiska och rumslig aspektser och perspektiv som varit temat här. 


\section{List of references}

Acuto, M. (2012) Ain't about politics? the wicked power-geometry of sydney's greening governance. International Journal of Urban and Regional Research, 36.2, 381-399.

Agnew, J. (2005) Space: Place. In P. Cloke, \& R. Johnston (Eds.), Spaces of geographical thought: Deconstructing human geography's binaries. London: Sage Publications Ltd.

Amin, A. (2007) Re-thinking the urban social. City, 11.1, 100-114.

Anderberg, S. \& Clark, E. (2013) Green sustainable Öresund region - or eco-branding Copenhagen and Malmö? In I. Vojnovic (Ed.), Sustainability: A global urban context. Michigan: State University Press.

Andersen, H. T. and Wichmann-Maththiessen, C. (1995) Metropolitan marketing and strategic planning: Mega events. A Copenhagen perspective. Danish Journal of Geography, 95.1, 71-82.

Andersson, I. (2013) Transferring green policies, how is it done? Experiences of policy sharing during the EU Open Days. Unpublished manuscript.

Andersson, I. \& Niedomysl, T. (2010) Clamour for glamour? City competition for hosting the Swedish tryouts to the Eurovision song contest. Tijdschrift Voor Economische En Sociale Geografie, 101.2, 111-125.

Anholt, S. (2004) Foreword to the first issue. Place Branding and Public Diplomacy, $1.1,4-11$.

Anholt, S. (2011) Beoynd the nation brand: The role of image and identity in international relations. In A. Pike (Ed.), Brands and branding geographies. Cheltenham: Edward Elgar.

Anholt, S. (2010) Places: Identity, image and reputation. Basingstoke: Palgrave Macmillan.

Arvidsson, A. (2011) Creativity, brands, finance and beyond: Notes towards a Theoretical perspective on City Branding. In A. Pike (Ed.), Brands and branding geographies. Cheltenham: Edward Elgar.

Ashworth, G. J., \& Voogd, H. (1990) Selling the city: Marketing approaches in public sector urban planning. London: Belhaven Press.

Ashworth, G. (2009) The instruments of place branding: How is it done? European Spatial Research and Policy, 16.1, 9-22.

Ashworth, G. J., Kavaratzis, M. \& Warnaby, G. (2015) The need to rethink place branding. In M. Kavaratzis, G. Warnaby \& G. J. Ashworth (Eds.), Rethinking place branding. Comprehensive brand development for cities and regions. Cham: Springer International Publishing.

Bader, I., \& Scharenberg, A. (2010) The sound of Berlin: Subculture and the global music industry. International Journal of Urban and Regional Research, 34.1, 7691.

Berglund, E., \& Olsson, K. (2010) Rethinking place marketing - a literature review. 50th ERSA Congress Jönköping, Sweden, 19th - 23th August, 2010-06-18 Special 
Session: Planning and Place Marketing - Theoretical Implications, http://wwwsre.wu.ac.at/ersa/ersaconfs/ersa10/ERSA2010finalpaper236.pdf. pp. 1-19.

Bickford-Smith, V. (2009) Creating a city of the tourist imagination: The case of Cape Town, 'The fairest Cape of them all'. Urban Studies, 46.9, 1763-1785.

Brand, P. (2007) Green subjection: The politics of neoliberal urban environmental management. International Journal of Urban and Regional Research, 31.3, 616632.

Brenner, N. (1998) Between fixity and motion: accumulation, territorial organization, and the historical geography of spatial scales. Environment and planning D, 16.4, 459-481.

Brenner, N. (1999) Globalisation as reterritorialisation: The re-scaling of urban governance in the European union. Urban Studies, 36.3, 431-451.

Burgess, J. A. (1982). Selling places: Environmental images for the executive. Regional Studies, 16.1, 1-17.

Castells, M. (1996) The rise of the network society. Cambridge, MA: Blackwell Publishers.

Chang, T. C. (2008) Art and soul: Powerful and powerless art in Singapore. Environment and Planning $A$, 40.8, 1921-1943.

Cochrane, A. \& Ward, K. (2012) Researching the geographies of policy mobility: Confronting the methodological challenges. Environment and Planning A, 44.1, 5-12.

Connell, J. \& Rugendyke, B. (2010) Creating an authentic tourist site? The Australian standing stones, Glen Innes. The Australian Geographer 41.1, 87-100.

Currid, E. (2009) Bohemia as subculture; "bohemia" as industry: Art, culture, and economic development. Journal of Planning Literature, 23.4, 368-382.

Dannestam, T. (2008) Rethinking local politics: Towards a cultural political economy of entrepreneurial cities. Space and Polity, 12.3, 353-372.

Dinnie, K. (2004) Place branding: Overview of an emerging literature. Place Branding, 1.1, 106-110.

Dinnie, K. (2011) Introduction to the theory of City Branding. In K. Dinnie (Ed.), City branding: Theory and cases. Basingstoke: Palgrave McMillan.

Dixon, T., Otsuka, N. \& Abe, H. (2011) Critical success factors in urban brownfield regeneration: An analysis of 'hardcore' sites in Manchester and Osaka during the economic recession (2009-10) Environment and Planning A, 43.4, 961-980.

Doel, M. \& Hubbard, P. (2002) Taking world cities literally: Marketing the city in a global space of flows. City, 6.3, 351-368.

Edensor, T. \& Millington, S. (2008) 'This is our city': Branding football and local embeddedness. Global Networks, 8.2, 172-193.

Ek, R. \& Hultman, J. (2007) Plats som produkt : Kommersialisering och paketering. Lund: Studentlitteratur.

Emelianoff, C. (2013) Local energy transition and multilevel climate governance: The contrasted experiences of two pioneer cities (Hanover, Germany, and Vaxjo, Sweden). Urban Studies, 51.7, 1378-1393.

Flowerdew, R. \& Martin, D. (2005) Methods in human geography: A guide for students doing a research project (Second ed.). Harlow: Prentice Hall.

Franzén, M. (2010) Varumärkets kortslutning?: 'Stockholm the Capital of Scandinavia'. Kultur \& Klasse, 109, 119-132.

Gonzalez, S. (2011) Bilbao and Barcelona 'in motion'. How urban regeneration 'models' travel and mutate in the global flows of policy tourism. Urban Studies, 48.7, 1397-1418.

Gotham, K. F. (2007) (Re)branding the big easy: Tourism rebuilding in post-Katrina New Orleans. Urban Affairs Review, 42.6, 823-850. 
Gustavsson, E., Elander, I. \& Lundmark, M. (2009) Multilevel governance, networking cities, and the geography of climate-change mitigation: Two Swedish examples. Environment and Planning C: Government and Policy, 27.1, 59-74.

Hall, T. \& Hubbard, P. (1998) The Entrepreneurial city: Geographies of politics, regime and representation. Chichester: Wiley.

Hallin, G. (1991) Slogan, image och lokal utveckling. In S. Berger (Ed.), Samhällets geografi. Uppsala: Nordisk Samhällsgeografisk Tidskrift.

Hankinson, G. (2015) Rethinking the place branding construct. In M. Kavaratzis, G. Warnaby \& G. J. Ashworth (Eds.), Rethinking place branding. comprehensive brand development for cities and regions. Cham: Springer International Publishing.

Hankinson, G. (2001) Location branding: A study of the branding practices of 12 english cities. Journal of Brand Management, 9.2, 127-142.

Hanna, S. \& Rowley, J. (2008) An analysis of terminology use in place branding. Place Branding and Public Diplomacy, 4.1, 61-75.

Hannigan, J. (2003) Symposium on branding, the entertainment economy and urban place building: Introduction. International Journal of Urban and Regional Research, 27.2, 352-360.

Harvey, D. (1982) The limits to capital. Oxford: Blackwell.

Harvey, D. (1989) From managerialism to entrepreneurialism: The transformation in urban governance in late capitalism. Geografiska Annaler. Series B, Human Geography, 71.1, 3-17.

Hospers, G. J. (2006) Borders, bridges and branding: The transformation of the Oresund region into an imagined space. European Planning Studies, 14.8, 1015-1033.

Hunt, J. D. (1975) Image as a factor in tourism development. Journal of Travel Research, 13.3, 1-7.

Jackson, P., Russel, P. \& Ward, N. (2011) Brands in the making: A life history approach. In A. Pike (Ed.), Brands and branding geographies. Cheltenham: Edward Elgar.

Jensen, J. L. \& Rodgers, R. (2001). Cumulating the intellectual gold of case study research. Public Administration Review, 61.2, 235-246.

Johansson, O. \& Cornebise, M. (2010) Place Branding goes to the Neighbourhood: The case of pseuo-Swedish Anderssonville. Geografiska Annaler. 92B.3, 187204.

Kavaratzis, M. (2004) From city marketing to city branding: Towards a theoretical framework for developing city brands. Place Branding, 1.1, 58-73.

Kim, C. (2010) Place promotion and symbolic characterization of new Songdo City, South Korea. Cities, 27.1, 13-19.

Klauser, F. (2011) The exemplification of 'Fan zones': Mediating mechanisms in the reproduction of best practices for security and branding at Euro 2008. Urban Studies, 48.15, 3203-3219.

Klein, N. (2000) No Logo. Taking aim at the brand bullies. Knopf Canada.

Koch, N. (2014) 'Building glass refrigerators in the desert': Discourses of urban sustainability and nation-building in Qatar. Urban Geography, 35.8, 1118-1139.

Kotler, P., Haider, D. H. \& Rein, I. J. (1993) Marketing places: Attracting investment, industry, and tourism to cities, states, and nations. New York: Free Press.

Larner, W., \& Laurie, N. (2010) Travelling technocrats, embodied knowledges: Globalising privatisation in telecoms and water. Geoforum, 41.2, 218-226.

Lewis, N. (2011) Packaging political projects in geographical imaginaries: The rise of nation branding. In A. Pike (Ed.), Brands and branding geographies Cheltenham: Edward Elgar. 
Lorentzen, A. (2009) Cities in the experience economy. European Planning Studies, $17.6,829-845$.

Lucarelli, A. \& Berg, P. (2011) City branding: A state-of-the-art review of the research domain. Journal of Place Management and Development, 4.1, 9-27.

Malecki, E. (2004) Jockeying for position: What it means and why it matters to regional development policy when places compete. Regional Studies, 38.9, 11011120 .

Martínez, J. G. (2007) Selling avant-garde: How Antwerp became a fashion capital (1990-2002). Urban Studies, 44.12, 2449-2464.

Massey, D. (1991) A global sense of place. Marxism Today, 38, 24-29

Massey, D. B. (1994) Space, place, and gender. Minneapolis: University of Minnesota Press.

Massey, D. B. (2005) For space. London: SAGE.

McCann, E. (2013) Policy boosterism, policy mobilities, and the extrospective city. Urban Geography, 34.1, 5-29.

McCann, E. (2011) Urban policy mobilities and global circuits of knowledge: Toward a research agenda. Annals of the Association of American Geographers, 101.1, 107-130.

McCann, E. (2009) City marketing. In R. Kitchin, \& N. Thrift (Eds.), International encyclopedia of human geography (2nd ed.). Oxford: Elsevier.

McCann, E. (2004) 'Best places': Interurban competition, quality of life and popular media discourse. Urban Studies, 41.10, 1909-1929.

McCann, E. \& Ward, K. (2010) Relationality/territoriality: Toward a conceptualization of cities in the world. Geoforum, 41.2, 175-184.

McNeill, D. \& McNamara, K. (2009) Hotels as civic landmarks, hotels as assets: The case of Sydney's Hilton. Australian Geographer, 40.3, 369-386.

McNeill, D. \& Tewdwr-Jones, M. (2003) Architecture, banal nationalism and reterritorialization. International Journal of Urban and Regional Research, 27.3, 738-743.

Niedomysl, T. \& Jonasson, M. (2012) Towards a theory of place marketing. Journal of Place Management and Development, 5.3, 223-230.

Ooi, C. (2011) Paradoxes of city branding and societal changes. In K. Dinnie (Ed.), City branding: Theory and cases. Basingstoke: Palgrave McMillan.

Paolo Russo, A. \& Sans, A. A. (2009) Student communities and landscapes of creativity: How Venice - 'The world's most touristed city' - is changing. European Urban and Regional Studies, 16.2, 161-175.

Paul, D. E. (2004) World cities as hegemonic projects: The politics of global imagineering in Montreal. Political Geography, 23.5, 571-596.

Pike, A. (2013) Economic geographies of Brands and Branding. Economic Geography, 89.4, 317-339.

Pike, A. (2011a) Conclusions: Brands and branding geographies. In A. Pike (Ed.), Brands and branding geographies (1st ed.). Cheltenham: Edward Elgar.

Pike, A. (2011b) Placing Brands and Branding: A socio-spatial biography of Newcastle Brown Ale. Transactions of the Institute of British Geographers, 36.2, 206222.

Pike, A. (2011c) Introduction: Brands and branding geographies. In A. Pike (Ed.), Brands and branding geographies (1st ed.). Cheltenham: Edward Elgar.

Pike, A. (2009) Geographies of brands and branding. Progress in Human Geography, $33.5,619-645$.

Pow, C. P. (2014) License to travel. City, 18.3, 287-306.

Prince, R. (2012) Policy transfer, consultants and the geographies of governance. Progress in Human Geography, 36.2, 188-203. 
Ritchie, J., Lewis, J., McNaughton Nicholls, C. \& Ormston, R. (2014) In Ritchie J., Lewis J., McNaughton Nicholls C. and Ormston R. (Eds.), Qualitative research practice: A guide for social science students and researchers (2nd ed.). London: Sage.

Rusten, G., Bryson, J. R. \& Aarflot, U. (2007) Places through products and products through places: Industrial design and spatial symbols as sources of competitiveness. Norwegian Journal of Geography, 61.3, 133-144.

Seisdedos, G. (2006) State of the art of city marketing in European cities. 42nd IsoCaRP Congress 2006, Istanbul. Quoted in Lucarelli, A. \& Berg, P. (2011) City branding: A state-of-the-art review of the research domain. Journal of Place Management and Development, 4.1, 9-27.

Skinner, H. (2008) The emergence and development of place marketing's confused identity. Journal of Marketing Management, 24.9-10, 915-928.

Smith, A. \& Strand, I. v. K. (2011) Oslo's new Opera House: Cultural flagship, regeneration tool or destination icon? European Urban and Regional Studies, 18.1, 93110.

Stålnacke, F. \& Andersson, I. (2014) Interna eller externa målgrupper? En studie om platsmarknadsföring i Göteborg och Stockholm. Geografiska Notiser, 72.1, 7-18.

Stern, P., \& Hall, P. V. (2010) Historical limits: Narrowing possibilities in 'Ontario's most historic town'. The Canadian Geographer, 54.2, 209-227.

Syssner, J. (2010) Place branding from a multi-level perspective. Place Branding and Public Diplomacy, 6.1, 36-48.

Torkington, K. (2012) Place and lifestyle migration: The discursive construction of 'glocal' place-identity. Mobilities, 7.1, 71-92.

Tuan, Y. F. (1974) Space and place: Humanistic perspective. Progress in Geography, 6, 211-252.

van Ham, P. (2008) Place branding: The state of the art. The Annals of the American Academy of Political and Social Science, 616.1, 126-149.

Waitt, G. (1999) Playing Games with Sydney: Marketing Sydney for the 2000 Olympics. Urban Studies, 36.7, 1055-1077.

Ward, S. V. (1998) Selling places: The marketing and promotion of towns and cities, 1850-2000. London: E \& FN Spon.

Warnaby, G., Ashworth, G., J., \& Kavaratzis, M. (2015) Sketching futures for place branding. In M. Kavaratzis, G. Warnaby \& G. J. Ashworth (Eds.), Rethinking place branding. Comprehensive brand development for cities and regions. Cham: Springer International Publishing.

Zimmerbauer, K. (2011) From Image to Identity: Building Regions by Place Promotion. European Planning Studies, 19.2, 243-260. 


\section{Appendix A. List of interviews and participatory observations}

\section{In-depth interviewees}

Ahlrot, Julia; Head of Environmental planning, Växjö municipality, 2014-02-06

Flores, Jesserina; Technical visits Co-ordinator, Växjö municipality, 2014-02-06

Flores, Jesserina; Technical visits Co-ordinator, Växjö municipality, 2014-10-16

Frank, Bo; Moderaterna, Mayor, Växjö municipality, 2014-05-09

Garzillo, Christina; policy expert, ICLEI European office, Freiburg, 2012-05-04

Karlsson, Thomas; Head of the Department of Commerce, Växjö municipality, 2011$01-24$

Kim-Hagdahl, Sohie, environmental planner, formerly in charge for technical visits (1998-2004), Växjö municipality, 2014-05-16

Mård, Sofia; Project Manager, Dynamic Växjö, Växjö municipality, 2011-01-25

Nilsson, Henrik; Cheif of Information, Växjö municipality, 2011-01-25

Nilsson, Henrik; Public Relations officer, Växjö municipality, 2014-02-05

Nilsson, Sarah; Head of Environmental Planning, Växjö municipality, 2011-01-25

Nilsson, Sarah; Project Manager, Energy Agency for South-east Sweden, former Head of Environmental Planning, Växjö municipality, 2014-02-06

Schöldberg, Per; Centerpartiet, Second vice chair, municipal government, Växjö Municipality, 2014-05-07

Svanberg, Charlotta; Socialdemokraterna, First vice chair, municipal government, Växjö Municipality, 2014-05-07

Thorsell, Johan; CEO, Sustainable Småland, former Technical visits Co-ordinator (2008-2011), Växjö municipality 2014-02-05

Thorsell, Johan; CEO, Sustainable Småland, former Technical visits Co-ordinator (2008-2011), Växjö municipality, 2014-05-16

\section{Participatory observations}

Breakfast member meeting, Expansiva Växjö, 2011-02-10

Board meeting, Sustainable Småland, 2014-05-08

Member meeting, Sustainable Småland, 2014-05-08

Member study trip "Plushuset", Sustainable Småland, 2014-05-08

Technical visit to Växjö municipality, visiting group: Swedish Institute, 2014-05-07 2014-05-08

Technical visit to Växjö municipality, visting group: Täby municipality, 2014-05-15 2014-05-16 